\title{
What drives local lending by global banks?*
}

\section{Stefan Avdjiev}

Bank for International Settlements
Uluc Aysun ${ }^{\dagger}$

University of Central Florida
Ralf Hepp

Fordham University

\begin{abstract}
We find that the lending behavior of global banks' subsidiaries throughout the world is more closely related to local macroeconomic conditions and their financial conditions than to those of their owner-specific counterparts. This inference is drawn from a panel dataset populated with bank-level observations from the Bankscope database. Using this database, we identify ownership structures and incorporate them into a unique methodology that identifies and compares the owner and subsidiary-specific determinants of lending. A distinctive feature of our analysis is that we use multidimensional country-level data from the BIS international banking statistics to account for exchange rate fluctuations and cross-border lending.

Keyword(s): Bankscope; G-SIB; bank-level data; global banks; BIS international banking statistics.

JEL Classification: E44; F32; G15; G21
\end{abstract}

\footnotetext{
${ }^{*}$ Most of the analysis for this project was conducted at the Bank for International Settlements under its research fellowship program. We are grateful for the research support that was received at the bank. We thank the participants of the 2017 Spring Midwest Macroeconomic Meetings, the Bank of Finland's Workshop on Banking and Institutions, Bank for International Settlements, Trinity College Dublin and Florida State University seminar series and the 2017 European Economic Association Meetings for valuable comments and suggestions. We thank Stijn Claessens, Jonathan Kreamer, Robert McCauley and Philip Wooldridge for helpful comments, as well as Bat-el Berger and Swapan Pradhan for excellent assistance with the BIS international banking statistics. The views expressed in this paper are those of the authors and do not necessarily reflect the views of the Bank for International Settlements.

${ }^{\dagger}$ Corresponding author: Department of Economics, University of Central Florida, College of Business Administration 4000 Central Florida Blvd., Orlando, Florida 32816-1991. Phone: +1 (530) 574-3951, fax: +1 (407) 823-3269, e-mail: uaysun@bus.ucf.edu.
} 


\section{Introduction}

Most of the discussion on the main determinants of global banking activity during the postcrisis period has focused on global drivers (also known as push factors) of cross-border bank lending flows. Those factors undoubtedly played a major role in the cross-country transmission of the financial crisis and the policy responses that it triggered. Nevertheless, the existing evidence does not make it clear whether these factors are more important than local drivers (i.e., "pull" factors), which are also a significant determinant of global bank flows according to empirical findings (Koepke, 2015; Cerutti et al., 2017). Furthermore, in studies that examine the lending behavior of global banks, hereafter internationally-active banks (IABs), much of the focus has been on cross-border lending as opposed to local lending of IABs through their foreign subsidiaries (Bruno and Shin, 2015a,b; Cerutti et al., 2016). The distinction between the two types of lending is important since the latter tends to be much more stable, growing less rapidly during expansions and contracting less sharply during retrenchments (Allen et al., 2011; Cecchetti et al., 2010; Cerutti and Claessens, 2016) and it has become a more important form of lending in the past two decades as illustrated in Figure $1 .^{1}$

In this paper we compare the relative importance of push and pull factors for the local (as opposed to cross-border) lending of IAB. Doing so allows us to gain insights into why IABs increase/decrease their presence across countries through their subsidiaries. This is a pressing issue at the moment as IABs have extensive global networks and account for a high share of total domestic credit in a very large number of countries. Drawing accurate inferences for financial stability without considering the decision making processes of these institutions is, thus, no longer feasible.

In our analysis, we focus on owner-specific (IAB-specific) and host-specific (local subsidiary and host nation-specific) factors as the source of push and pull effects, respectively.

\footnotetext{
${ }^{1}$ The 2008 Global Financial Crisis provided another vivid example of this disparity (see, Avdjiev et al., 2012; Fender and McGuire, 2010; Ongena et al., 2013).
} 
This particular definition of push and pull effects allows us to compare the independent effects of the two factors as we describe below. We should note that the term "push effects" is also used to describe the effects of systematic shocks such as global risk aversion and U.S. monetary policy shocks on IAB lending. In addition to capturing the idiosyncratic effects of these shocks on IAB lending, our definition of push factors further allows us to account for any relative deterioration/improvement in the financial condition of banks. Despite potential differences in interpretation, we often refer to our host and owner-specific determinants of IAB lending as pull and push factors, respectively, to simplify terminology.

Our main conclusion is that pull factors are more important for the local lending of IABs than push factors. The biggest hurdle on the path to making this comparison is the independent identification of the two factors. Put simply, are IABs lending more in a given country because their own financial conditions are better or is the higher level of lending explained by local factors? While both mechanisms are potentially at play, what are their independent effects? To answer these questions, we use a unique methodology that is centered on the relative local lending behavior of IABs' subsidiaries.

To identify pull effects, we compare the lending behavior of subsidiaries affiliated with the same parent IAB. By so doing, we are able to suppress any IAB-specific factors (or any other push shock transmitted through IABs) that may symmetrically affect subsidiaries' lending decisions. Throughout the paper, we use two sets of pull factors associated with local lending: (i) macroeconomic variables that gauge the local cost of funding and the strength of borrowers' balance sheets and (ii) indicators of local subsidiaries' financial health. To visualize how we execute this identification strategy, assume that a German IAB $g$ has a subsidiary $g^{b}$ in Brazil and that the balance sheets of Brazilian borrowers are getting stronger due to an economic expansion, which is not observed in the other countries where $g$ has subsidiaries. A comparison of the lending behavior of $g^{b}$ with its sister subsidiaries in other countries then allows us to determine the effects of the expansion on local lending that are independent of IAB related (push) factors. A similar illustration can be made by using 
the financial condition of subsidiary $g^{b} .^{2}$

To identify the independent effects of push factors, we reverse our methodology and compare the lending behavior of subsidiaries that are located in the same country, but have different parent IAB. Push factors here similarly fall under the two main (bank-specific and macroeconomic) categories mentioned above. This time, however, these factors describe the financial conditions of the IABs and the macroeconomic conditions in the country in which they are headquartered. Continuing with our hypothetical illustration, now assume that a US IAB, $u$, also lends in Brazil through its subsidiary $u^{b}$. Suppose that IAB $u$ is experiencing a deterioration in the quality of its assets while IAB $g$ is not. By comparing the lending behavior of $u^{b}$ and $g^{b}$, our methodology neutralizes any symmetric effects that local conditions may have on the subsidiaries' lending when measuring the impact of the decline in the asset quality of IAB $u$. As a part of this methodology, we also control for various subsidiary-specific variables to hone in on the IAB related push factors.

The two distinct contributions of this paper are the investigation of the local lending behavior of global banks and the utilization of bank-level data in doing so. The existing literature primarily uses aggregate (country-level) data to distinguish just among borrowing (but not lending) countries and focuses on cross-country capital flows. The few papers that also distinguish among lenders (Avdjiev and Takáts, 2016; Aysun and Hepp, 2016; Cerutti and Claessens, 2016) have done so at the lending country (i.e. national banking system) level and have used cross-country data to do so (e.g. Fratzscher, 2012 and Houston et al., 2012). ${ }^{3}$ By contrast, we use bank-level data which allows us to control for heterogeneity

\footnotetext{
${ }^{2}$ We should also mention that by measuring and comparing the growth rate of macroeconomic variables and financial ratios over time we are also suppressing any relatively time-invariant institutional factor that may affect the level of lending (but not the growth rate of lending). The regulatory asymmetries that explain the relative level of international bank flows in Houston et al. (2012), for example, are very stable over time compared to the financial and macroeconomic variables that we use in our analysis.

${ }^{3}$ Fratzscher (2012) compares the relative importance of push versus pull factors in driving net capital flows. His analysis differs along a couple of important dimensions from ours. First, he studies aggregate capital flows in general, whereas we focus on bank lending in particular. Second, he examines cross-border flows, while we study local lending by foreign banks. Houston et al. (2012) also account for both pull and push factors of international banking flows. Their approach is distinctly different from ours. First, like Fratzscher (2012), they use country-level (and not bank-level) data. Second, they exclusively focus on the effects of the level of regulations on the level of banking flows (while we focus on relative growth rates of
} 
among lending banks, even if they have the same nationality. The bank-level financial data are obtained from the Bureau van Dijk Bankscope database. We use this database also to infer the ultimate owners of global bank subsidiaries and focus on the local lending behavior of these institutions. The financial variables for both subsidiaries and owners are from the consolidated statements compiled by Bankscope. In our dataset, these variables are at the annual frequency (1995 to 2014) and they allow us to directly account for owner and subsidiary-specific factors that may be affecting lending. Our dataset consists of 275 owner/subsidiary country pairs that include both advanced and developing economies.

There are two missing components of the lending data in Bankscope that complicate our analysis: the currency composition of loans and the share of cross border lending are not reported. The first deficiency makes it hard to determine whether changes in lending are due to pull factors or simply due to currency fluctuations. For example, if a subsidiary lends only in euros while all of its sisters lend in US dollars, a euro appreciation would result in a mechanical increase in the former subsidiary's lending reported in the data, which is expressed in US dollars for every bank in our dataset, even if its actual lending expressed in euros remains the same. A similar mismeasurement of pull effects could occur if a subsidiary's loans are mostly cross-border rather than local. To deal with these issues, we incorporate the BIS locational banking statistics (LBS) and the BIS consolidated banking statistics (CBS) into our analysis. Using the LBS and CBS, we extract the currency composition of local lending and the share of cross-border lending for each (subsidiary/owner) country pair. We then apply these breakdowns to our bank-level panel to obtain exchange rate adjusted loan growth rates and to account for cross-border lending. This aspect of our analysis is necessary for an accurate comparison of push and pull factors across countries. To the best of our knowledge, it has not been implemented at the bank-level before. We should point out here that while restricting our dataset with country-level data would be problematic if the number of banks were large, the country pairs in our sample typically have a small number

variables). Third, they use BIS data on banks' foreign (cross-border plus local) lending. By contrast, we focus exclusively on local lending. 
of banks (with a sample average of 3.89 and a sample median of 2). Furthermore, restricting our sample to country pairs with a small number of banks does not change our conclusions.

Using a difference general method of moments (GMM) dynamic panel estimator, we find that the variables capturing macroeconomic conditions and borrowing costs in the countries where the subsidiaries of IABs are located (pull factors) are more important determinants of local lending than the corresponding variables for the countries in which their parent IABs are headquartered (push factors). Our results also suggest that the sensitivity of lending to pull factors is economically meaningful.

Turning to financial variables, while we do not observe a large disparity between the statistical significance of pull and push factors, we find that the economic significane of the former is considarably greater than that of the latter. The financial variables that we use constitute the entire population of the financial ratios in Bankscope. They are classified under four groups of ratios which measure (i) capital adequacy, (ii) asset quality, (iii) performance and (iv) liquidity. Our results show that subsidiary lending is significantly related to the liquidity of the subsidiaries (the pull factor). For the remaining three categories, there is no clear difference between the statistical significance of owner and subsidiary ratios (the push and pull factors, respectively). Our descriptive statistics suggest that it may be misleading to use statistical significance to draw conclusions about (relative) economic significance as the host nation-specific macroeconomic variables and subsidiary-specific ratios in our dataset tend to have considerably larger standard deviations than lending nation and owner specific variables. To account for this disparity, we standardize our main independent variables so that their coefficients represent the lending responses to a one-standard-deviation change in the independent variable. We find that the subsidiaries' financial ratios, measured in this way, are more important determinants of their lending than their owners' ratios.

In addition to being based on a large set of macroeconomic and financial variables, our results are also robust to a variety of additional tests. Our key conclusion that pull factors are more important remains unchanged after all of the following robustness checks: using 
two alternative ways of controlling for cross-border lending, accounting for the number of banks, accounting for lending market shares, allowing for an interaction between pull and push factors, using alternative methodologies to account for mergers and acquisitions (M\&A) and accounting for capital controls and lending shares.

As indicated in Obstfeld (2012), it has become very difficult to associate cross-country capital flows with trade imbalances and to ignore the role that global banks play in driving these flows. This view has materialized in a majority of research in the field of international macroeconomics ensuing the 2008 financial crisis. For example, Alpanda and Aysun (2014), Davis (2010), Gertler and Karadi (2011), Kollmann (2013), Kollmann et al. (2011) and Meh and Moran (2010) have incorporated global banks in open economy models to investigate how global shocks are transmitted to local economies through global banks. ${ }^{4}$ We approach the subject from a different angle. Instead of assessing the effects of global banking on business cycles, we try to understand the ebbs and flows of global bank lending in host nations. This agenda is closer to research in international finance, such as Cetorelli and Goldberg (2012a, 2012b), Bruno and Shin (2015a), Buch et al. (2016), Rey (2015), Schnabl (2012) and Shin (2012), which reveals a strong cross-country transmission of global financial push shocks. ${ }^{5}$ In our paper we put an equal degree of emphasis on pull factors and find that while some push factors are significant determinants of global bank lending, pull factors such as the financial condition of subsidiaries and local macroeconomic conditions are more important.

As mentioned, the main difficulty we face is in identifying the independent effects of pull and push factors. This difficulty also explains the scarcity of research on pull effects. The challenge here is to link borrower balance sheets with lending while controlling for any lender-

\footnotetext{
${ }^{4}$ Earlier work identifies two effects of global banks: support and substitution effect. The evidence on the relative strength of these effects is mixed. While studies such as Buch (2000), Dahl et al. (2002), De Haas and Van Lelyveld (2006), Goldberg (2002), Hernandez and Rudolph (1995), Jeanneau and Micu (2002), Martinez Peria et al. (2002) and Morgan and Strahan (2004) find that the cross-country movement of global banks' funds that depends on borrowers' balance sheets (the substitution effect) destabilizes economies, De Haas and Van Lelyveld (2010), Cetorelli and Goldberg (2012b), Crystal et al. (2002), Dages et al. (2000), and Peek and Rosengren (2000) find that global banks shift funds across subsidiaries to support lending.

${ }^{5}$ Forbes and Warnock (2012), Rey (2015), Miranda-Agrippino and Rey (2015), Cerutti et al. (2015) examine the drivers of cross-border bank lending as one of several main components of global capital flows.
} 
specific factors. A solution comes from a different line of work. Specifically, few studies in the credit channel of monetary transmission literature either use loan level data to link terms of lending, borrower and lender balance sheets directly (e.g. Aysun and Hepp, 2013; Jimenez et al., 2009) or compare the state-level lending of subsidiaries with the same parent bank (e.g. Ashcraft and Campello, 2007; Aysun and Hepp, 2011) to identify state-specific pull factors. ${ }^{6}$ While our approach is closer in spirit to the latter strategy, we compare balance sheets across countries and use financial ratios of subsidiaries to identify pull factors. The second part of our analysis, comparing the lending of subsidiaries that operate in the same country, but are owned by different IABs, has not been used in the credit channel literature to the best of our knowledge. It is also different from the prevalent methodology in the literature on push factors. Specifically, while this methodology captures the direct impact of global financial shocks on IAB lending, we focus on the relative lending behavior of banks and thus any relative impact that global shocks may have on IABs' affiliates. Doing so, weeds out any pull effects that may be impacting local lending coincidentally with push effects.

There are two opposing international banking business models that could affect the relative importance of pull and push factors as drivers of foreign subsidiaries' local lending. On the one hand, there is empirical evidence of centralized decision-making (decisions made by IABs) and its execution through internal capital markets (Buch et al., 2016; Campello, 2002; Cetorelli and Goldberg, 2012a; De Haas and Lelyveldb, 2010; Houston et al., 1997). On the other hand, there is also evidence of decentralized activity (e.g. autonomous country-specific decision making, using local funding to finance local lending, etc.) in global banking (see for example, Avdjiev and Takáts, 2014; Fiechter et al., 2011). While we find evidence for the existence of both international banking business models, our results suggest that the latter may be more important for local lending. Claessens (2017) and Fiechter et al. (2011) offer clues as to why decentralized/regional banking has become more important recently. ${ }^{7}$

\footnotetext{
${ }^{6}$ While a direct way to identify pull effects is to use a loan-level anlaysis, data are often limited/complex. In Aysun and Hepp (2013) loans are often syndicated, thus severing the link between borrowers and lenders.

${ }^{7}$ First, following the financial crises of the 1990s, there has been a large degree of privatization in the banking industry and higher level of brick and mortar foreign banking presence. Banks have also tapped into
} 


\section{$2 \quad$ Identifying pull and push effects}

Our first step is to identify the ownership structures for the banks in our sample. Below, we discuss how we proceed along this direction by using the Bankscope database. It is, however, convenient at this point to mention that the owners in our sample are the 53 largest commercial bank holding companies that own subsidiaries throughout the world. Our goal is to determine why and how the loans of these subsidiaries change over time. In pursuing this goal, we face a major obstacle: while banks lend in different currencies, their loans are reported only in local currency. Comparing the growth rate of these loans, after converting them to a common currency (e.g., US dollar), does not give an accurate picture of how active banks are in the lending market, as loans are not adjusted for currency fluctuations. Take, for example, a subsidiary lending a fixed amount of local currency in each period in a given country. If there is an $x$ percent appreciation of this country's currency, then looking at unadjusted figures, one could inaccurately conclude that the subsidiary is $x$ percent more active in lending. While currency appreciation may be linked indirectly to the loan demand that the bank faces, the unadjusted change in its loan growth rate is directly linked to the currency appreciation. Adjusting for exchange rates is therefore a critical part of our analysis, especially given that we are comparing banks' lending across countries.

To adjust for exchange rate fluctuations, we use BIS locational banking statistics (LBS), which contain the currency composition of loans available for each (lending/borrowing country) pair in our sample (see the next section for a detailed description). Let $l_{i j, t}$ denote the

the retail market both in terms of lending and funding, which has decreased the required level of support from their parent IABs. In addition, local funding has also increased for subsidiaries, further detaching them from their parents. Second, after the Global Financial Crisis (GFC), IABs have deleveraged their balance sheets by decreasing their cross-border lending due to the stricter regulatory requirements. In the meantime, their subsidiaries' lending has remained robust. Third, there has been a transition of bankruptcy resolution from a universal system (where bankruptcy applies to the whole organizational structure of an IAB) to a more territorial system, in which subsidiaries are insulated from the financial troubles of their parent. This has decreased the level of scrutiny that subsidiary lending decisions would otherwise receive. Meanwhile, there is evidence that asymmetric information and management practices have not played an important role in driving decentralization in international banking, as there is common risk management practices and high level of information sharing within a banking group. 
total end of period stock of loans, in US dollars, of subsidiary $i$ that is owned by parent IAB $j$ (not necessarily located in the same country as bank $i$ ) at time $t$ and let $l_{i j, t}^{n}$ denote the amount of bank $i$ loans, also in US dollars, that are extended in currency $n$ so that

$$
l_{i j, t}=\sum_{n=1}^{Z} l_{i j, t}^{n}
$$

Here $Z$ denotes the number of currencies that bank $i$ lends in. ${ }^{8}$ After decomposing loans by currency, we convert US dollar loans to the currency in which they were extended as

$$
l_{i j, t}^{n, c}=l_{i j, t}^{n} / e_{n, t}^{e o p}
$$

where $e_{n, t}^{e o p}$ is the end of period exchange rate (expressed as US dollars per currency $n$ ) and $l_{i j, t}^{n, c}$ are the loans extended and denominated in currency $n$. After applying this calculation to each time period, we measure the change in bank $i$ 's loans in currency $n, d l_{i j, t}^{n, c}$, as

$$
d l_{i j, t}^{n, c}=l_{i j, t}^{n, c}-l_{i j, t-1}^{n, c}
$$

Next we convert $d l_{i j, t}^{n, c}$ back to US dollars by multiplying it with the average exchange rate during period $t$, denoted by $e_{n, t}^{a}$. The exchange rate adjusted change in lending, $d l_{i j, t}$, and the adjusted lending growth rate, $\lg _{i j, t}$, are then computed as

$$
\begin{gathered}
d l_{i j, t}=\sum_{n=1}^{Z} e_{n, t}^{a} d l_{i j, t}^{n, c} \\
\lg _{i j, t}=\log \left(l_{i j, t-1}+d l_{i j, t}\right)-\log \left(l_{i j, t-1}\right)
\end{gathered}
$$

This variable is then used to compute the dependent variable in our estimations.

Our second step is the identification of factors that determine banks' lending behavior.

\footnotetext{
${ }^{8}$ The BIS LBS data contains breakdowns for claims denominated in US dollars, euros, and yen. We assume that, for each (host country/lending bank nationality) pair and at each point in time, the remaining claims are distributed proportionately among the above three major currencies.
} 
We categorize these factors under two groups: pull and push factors. When analyzing pull factors, our focus is on the relative financial condition of the subsidiaries and the macroeconomic conditions of the country in which these subsidiaries lend. In identifying the effects of these factors, we control for owner-specific conditions by comparing the loan growth rate of a subsidiary to the average loan growth of all the subsidiaries that its parent IAB owns such that,

$$
l d_{i j, t}^{h}=\lg _{i j, t}-\overline{\lg }_{j, t}
$$

where $l d_{i j, t}^{h}$ represents the exchange rate adjusted loan growth rate of bank $i$ that is owned by IAB $j$ relative to the average loan growth rate across all subsidiaries owned by IAB $j$. This key feature of our analysis signals to us how closely attached the lending decisions of banks are to their parent IAB. If, for example, financial conditions of IABs are the overriding determinant of their subsidiaries' lending then we would not expect to find any relationship between subsidiaries' lending and host specific factors. We test this hypothesis by estimating the following model:

$$
l d_{i j, t}^{h}=\sum_{k=1}^{2} \lambda_{k}^{h} l d_{i j, t-k}^{h}+\gamma_{1}^{h} h f d_{i j, t-1}+\sum_{m=1}^{M} \alpha_{m}^{h} o f_{j, t-1}^{m}+\varepsilon_{i j, t}^{h}
$$

where $h f d_{i j, t}$ is the host-specific factor that reflects either the financial conditions of the subsidiary or the local macroeconomic conditions. In our estimations we use various macroeconomic and subsidiary-specific variables for $h f d_{i j, t}$ and we similarly measure it relative to its average computed across all of bank $i$ 's sister subsidiaries. In equation (7) we also include owner specific factors, $o f_{j, t-1}^{m}$, to control for any residual effects of the owners' condition that our methodology may not be picking up.

Estimating equation (7) allows us to determine whether subsidiary lending is detached from the overall financial conditions of owners or not. This does not, however, give us a way to measure the strength of the influence that owners have on their subsidiaries as equation (7), by design, measures the importance of local and subsidiary-specific factors only. To 
capture this influence, we invert our methodology so that our perspective is now from the vantage point of host nations. Specifically, by focusing on a given country, we compare the lending behavior of all global bank subsidiaries in this country that are owned by different parent IABs. The relative lending growth rate, denoted by $l d_{i j, t}^{l}$, is then given by

$$
l d_{i j, t}^{l}=\lg _{i j, t}-\overline{\lg }_{i, t}
$$

where the average loan growth rate, $\overline{\lg }_{i, t}$, is measured across all the banks that lend in the same country as bank $i$. The corresponding independent variable that is the main focus here is $o f d_{i j, t}$ and it measures the conditions of the owner of bank $i$ relative to all other owners that have subsidiaries in the same country as bank $i$. These two variables are incorporated into the following model,

$$
l d_{i j, t}^{l}=\sum_{k=1}^{2} \lambda_{k}^{l} l d_{i j, t-k}^{l}+\gamma_{1}^{l} o f d_{i j, t-1}+\sum_{m=1}^{M} \alpha_{m}^{l} h f_{i, t-1}^{m}+\varepsilon_{i j, t}^{l}
$$

where $h f_{i, t-1}^{m}$ are subsidiary and host-specific factors that control for local conditions. Under this formulation, we are effectively controlling for any local factors that affect subsidiaries' lending symmetrically and focus on the effects of parent IABs on local lending. To help visualize this channel of transmission, say a given country experiences an expansion that prompts a higher demand for bank loans. Now assume that out of all the foreign owned banks, bank $i$ 's parent is the only one experiencing a deterioration in its financial conditions (or a macroeconomic deterioration in the country of the parent IAB). In this case, the coefficient of $o f d_{i j, t-1}$ captures to what extent this deterioration is transmitted to bank $i$ 's lending.

\section{Data and estimation methodology}

We draw our data from three sources: Bureau van Dijk Bankscope, BIS locational and consolidated banking statistics, and International Financial Statistics (IFS) databases. The 
definitions of the variables that we use are provided in Appendix A.

Our bank-level observations are available annually. Banks' ownership structures are from the Bankscope database and they cover the period 1995 to 2014. To construct our dataset by using this database, we follow several steps/restrictions. First, we exclude all banks that are not classified as commercial. This eliminates Specialized Governmental Credit Institutions, Multi-lateral Governmental Banks and Central Banks whose behavior may be driven by factors outside of the identification framework discussed in the previous section. While a majority of the financial statements in the Bankscope database are reported at the end of the year, there are some banks with quarterly observations. To harmonize the dataset we only include end of year statements. Second, we identify banks that are, on average, in the top 5 percent. We do so by ranking the banks in each year based on their total assets (in US dollars). We then take the average of these rankings over the sample period and keep banks that have an average ranking in the top 5 percent. These banks are the owners that we refer to as IABs. We then identify the banks that these IABs own by using the ownership structure module of Bankscope. While it is possible to determine the different layers of ownership (immediate, domestic and global ultimate) within this module, we focus on global ultimate ownership since it is more consistent with our methodology that focuses on the global functioning of internal capital markets. While the ultimate owners in Bankscope are banks that own more than 50 percent of a subsidiary, we should mention that a majority of the ownership shares are 100 percent. Furthermore, in order to rule out the confounding effects of potential mergers and acquisitions activity, we exclude observations with loan growth rates above 200 percent and below -200 percent. ${ }^{9}$ As a third step, we combine the financial and structural (such as location and bank history) data of the owners and subsidiaries to form our dataset. To make the cross-country comparison in equation (7) feasible, we identify and keep owners that have subsidiaries in at least two countries.

The main dependent variables in our estimations are constructed by using the total loans

\footnotetext{
${ }^{9} 200$ percent corresponds roughly to a 4 standard deviation band around the mean loan growth rate in our sample. We follow an alternative strategy to account for M\&A activity in Section 4.3.2.
} 
of subsidiaries. We convert these loans to US dollars and measure their growth rate over the previous year. At this stage, we incorporate BIS data on the currency composition of bank claims to adjust our lending growth rates for exchange rate fluctuations as described above. The BIS data that we use are at the country level (available for nationality/residence pairs) and come from two sources. We obtain the currency composition of local claims in foreign currency from the locational banking statistics by nationality (LBSN) for the set of 44 countries which report data to the BIS LBS. These data are reported for locally-booked claims denominated in foreign currencies and contain individual currency breakdowns for loans denominated in US dollar, euro, and yen. From these, we infer lending in foreign currency that cannot be allocated to any currency ("other foreign currency" claims) as the difference between total foreign currency claims and the sum of claims denominated in the above three currencies. ${ }^{10}$ For each country pair and time period, we perform the exchange rate adjustment for "other foreign currency" loans, using the assumption that the currency shares in that category are in line with the respective reported (US dollar, euro and yen) shares for the same country pair and time period. The remaining group of host countries (i.e., those not reporting data to the BIS LBS) tend to be mostly smaller economies. For them, we can observe total local claims in local currency and total local claims in all currencies from the BIS consolidated banking statistics. While the existing data do not contain the currency decomposition of local claims in foreign currency for this group, we observe that the share of local currency lending tends to be quite high (above 90 percent for an overwhelming majority of these countries). That is why, in our baseline estimations, we apply the exchange rate adjustments for this group of countries, while assuming that all local loans are denominated in the local currency of the respective host country.

There are two sets of independent variables that are the focal point of our baseline analysis. The first set consists of country-specific observations for GDP, unemployment and deposit rates that in turn help us approximate the local macroeconomic conditions and the

\footnotetext{
${ }^{10}$ The share of loans in currencies other than US dollar, euro, and yen for the 44 LBS reporting countries is 16.8 percent on average (both across time and country pairs) in our sample.
} 
local cost of funding in the countries. We refer to these as macroeconomic variables. Besides GDP and unemployment, there are, of course, various other macroeconomic variables that are related to borrower balance sheets and their probability of default. These two variables, however, constitute the broadest and the most harmonized measures of economic activity in the IFS database for the group of countries in our sample. As mentioned above, while global banks use their internal capital markets effectively to provide funding to their subsidiaries (Cetorelli and Goldberg, 2012a), it is also true that these subsidiaries use local funding. This is the reason why we include deposit rates as a macroeconomic indicator of local conditions in our baseline estimations. We broaden the definition of local funding by considering various other local interest rates in our sensitivity analyses. In the second set, we have ownerspecific and subsidiary-specific financial ratios that measure capital adequacy, asset quality, performance, and liquidity. In our baseline analysis these features are captured by the total capital (TC), loan-loss-reserves-to-gross-loans (LLR/TL), return on average equity (ROAE) and liquid-assets-to-total-short-term-funding-and-deposits (LA/STFD) ratios, respectively. We choose these ratios since they are commonly used indicators of the four financial aspects of banks. We do, however, extend this baseline set of variables later in our paper to cover the entire population of the ratios (measuring the four features mentioned above) in the Bankscope database in our sensitivity analyses.

All macroeconomic variables described above, as well as the dependent variables, are transformed so that they represent percentage changes over the previous year in our model. The ratios, by contrast, are measured as the difference between their levels at time $t$ and $t-1$ since they can be close to zero or negative at times. The second layer of differencing is applied to our main dependent and independent variables by following the procedure discussed in the previous section. Specifically, following equation (6) we measure the difference between the exchange rate adjusted loan growth rate of a subsidiary and the mean loan growth computed across all of its sister subsidiaries that belong to the same parent. In equation (7), the corresponding independent variable is measured similarly as the difference between 
the growth rate of the subsidiary or host-specific variable (either the subsidiary's ratios or the host nation's macroeconomic variables) and the corresponding mean value computed across sister subsidiaries or the host nations in which these subsidiaries reside. The control variables in equation (7) are the owners' ratios - TC, LLR/TL, ROAE, and LA/STFD - differenced across time. Conversely, the main dependent and independent variables in equation (9) represent deviations across owners that have subsidiaries in the same country and the control variables are the baseline ratios for the subsidiary.

Restricting the sample as described above leaves us with 53 large banks and 602 of their subsidiaries. While we do not list the names of these banks, we should note that all private commercial banks designated as a Global, Systemically Important Bank (G-SIB) by the Financial Stability Board are in our list of owners. ${ }^{11}$ As displayed in Table 1, the total assets of these owners are considerably larger (approximately 16 times) than their subsidiaries' assets. The owners are located in 18 countries and there are 95 countries where subsidiaries reside in our baseline sample. We have observations for 275 pairs of these countries (the list of host and lending nations are listed at the bottom of Table 1). When we incorporate the data on the currency composition of local lending in foreign currency, the number of lenders stays the same but the number of borrowers and the number of country pairs decrease. The table also shows that the number of subsidiaries per owner (an average of 19.9) and the number of subsidiaries owned by global banks per country pair are large enough for us to exploit the cross-subsidiary variation in our analysis.

In the next section, we measure the statistical significance of owner- and subsidiaryspecific financial ratios and macroeconomic variables. It is important to note at this point that these variables have different means and standard deviations (both across factors and types of banks) as reported in Table 1 (for example, host-specific variables usually have larger standard deviations). It is, therefore, important to take account of these differences when comparing the magnitudes of the coefficients and drawing inferences for economic

\footnotetext{
${ }^{11}$ For the list of these banks see, http://www.fsb.org/2016/11/fsb-publishes-2016-g-sib-list/.
} 
significance.

In the BIS IBS database, there are, naturally, more reporting lending countries than in our sample since we restrict our sample to countries that have at least one IAB. The number of countries that are hosts to the subsidiaries and the number of banks per country pair are slightly lower in our sample as well. The latter disparity is due to the standalone banks and banks that are owned by smaller IABs (IABs that are not in our list of owners) in the BIS statistics. This is also the main reason why the total number of banks in our sample is smaller. For the 44 countries that report BIS LBS data, foreign currency claims are roughly 25 percent of local claims in all currencies (local claims in local currency plus local claims in foreign currency). As explained above, we use these statistics, at the country pair level, when adjusting for currency fluctuations. We find that this adjustment is large and makes a noticeable difference in our estimations as we explain in the next section. Comparing the loan growth rates with and without the exchange rate adjustment (computing the absolute value of the difference between the two measures), for example, we find an average difference of 6.6 percent in our sample period. While it is possible to use the BIS CBS to estimate the share of local claims denominated in foreign currency (in total local claims) for the remaining countries, the currency decomposition of these loans is not reported. That said, this share is small (less than 10 percent) for the majority of these countries. That is why we assume that all loans are denominated in local currency when computing the exchange rate adjusted loan growth rates in these countries in our baseline estimations. Furthermore, we also investigate whether our main inferences remain the same when we use data for only the 44 currency composition reporting countries later in the paper.

Another feature of Bankscope that can potentially complicate our analysis is that the loan amounts reported in this database include cross-border loans. If these shares are large then the link between the local macroeconomic variables and loan growth modeled in equation (7) would be inconsistent with data and it could potentially produce a weak link between the two variables. While local lending represents the majority (approximately three-quarters) 
of lending in our sample of subsidiary/host country pairs, we modify our analysis in several different ways to account for cross-border lending and check the robustness of our main results in Section 4.

To estimate equations (7) and (9) we use the difference GMM dynamic panel estimator of Arellano and Bover (1995). ${ }^{12}$ This methodology is designed for panels that, like ours, have a relatively smaller time dimension. It accounts for panel level fixed/random effects and idiosyncratic errors that are heteroskedastic and correlated across time. The methodology is also advantageous since it does not require all independent variables to be strictly exogenous and the endogenous variables in levels are instrumented with the lags of their first differences. In our estimations, we use the first lags of all the baseline variables as instruments. For all the different model specifications that we use in this paper, the tests of over-identifying restrictions indicate that instruments as a group are valid and exogenous. ${ }^{13}$ In all of these estimations, we apply the Windmeijer's finite-sample correction as it is well-known that the standard two-step estimation, though robust, yields downward biased standard errors.

\section{Results}

In this section we report and discuss our baseline results that are obtained from the estimation of equations (7) and (9), we incorporate a broader set of macroeconomic variables and financial ratios into our analysis, we conduct sensitivity analyses that correspond to various sample restrictions and we measure and compare the economic significance of the determinants of subsidiary lending.

\subsection{Baseline results}

Our baseline results obtained from the estimation of equation (7) are reported in Table 2. The spotlight here is on the coefficients appearing in the first row. The first set of these indicates that the subsidiaries lend relatively more when their host country has an economic

\footnotetext{
${ }^{12}$ We use the code developed by Roodman (2009) to apply this methodology in STATA.

${ }^{13}$ For these tests we report the Hansen $J$ statistic since its alternative, the Sargan statistic, is not robust to heteroskedasticity or autocorrelation.
} 
expansion, lower unemployment and lower deposit rates. To clarify the interpretation of these coefficients, it is useful to think about the following scenario: Assume that bank $x$ operates in Brazil and is owned by a large IAB $m$ that also owns banks in other countries. Now assume that the Brazilian economy is experiencing a 1 percent increase in its real GDP and the rest of the economies in the world are not growing. The number 0.7437 reported under the GDP column then implies that bank $x$ increases its loans by 0.7437 percent more than the mean loan growth rate across all of its sister subsidiaries that belong to IAB $m$. The coefficients of the unemployment ratio and deposit rates have a similar interpretation (the deposit rate coefficient represents the percent response of lending growth rate to a one basis point change in the rate).

In a second set of estimations, we replace the host-specific macroeconomic variables with subsidiary-specific financial ratios in equation (7). The results indicate that better capitalized, more liquid and profitable banks with higher asset quality expand their lending by more compared to their sister subsidiaries. For most of the asset quality ratios in Bankscope, as well as our baseline measure, an increase in the ratio implies a decline in quality. In reporting our baseline results in Table 2 and 3, we reverse the sign of the coefficient so that an increase in the ratio indicates an increase in quality. We do, however, report the actual coefficient values in our sensitivity analyses below.

By design, the coefficient values of bank ratios, similar to deposit rate coefficients, show the percent change in lending growth corresponding to a one basis point increase in the ratio relative to the IAB-specific mean. The estimated value of the capital adequacy coefficient, for example, implies that if a bank's total capital ratio is one percent higher than that of its sister subsidiaries, its lending growth is 0.58 percentage points higher than that of its sisters. We should reiterate at this point that we cannot compare these coefficients to draw conclusions regarding economic impact since the ratios and the macroeconomic variables have very different standard deviations. The same can be said for the comparison between equations (7) and (9) since there is a similar disparity between the standard deviations of 
bank/host nation and owner-specific variables. We will scrutinize the economic significance of these coefficients later in the paper.

Table 2 also shows that the owner-specific coefficients are mostly insignificant. This result suggests either that our methodology of measuring deviations across sister subsidiaries is effective in controlling for owner-specific determinants of subsidiary lending or that the internal capital markets are not as important and the lending decisions of subsidiaries are formulated independently. Based on the inferences that we draw by using a broad set of owner-specific factors (these are reported below), we reject the latter hypothesis. In our estimations, we find no evidence for second-order serial correlation in the error term or any evidence for the invalidity of the instruments. This is also true for all the remaining estimations in our paper.

Next, we invert our methodology to study the owner-specific determinants of subsidiary lending as we describe in our discussion of equation (9). The results that demonstrate the strength of this channel are reported in Table 3. The main conclusion here is that ownerspecific determinants (our baseline measures of macroeconomic and financial conditions) are not as significant; only the coefficients of GDP growth in the owner's country and the owner's return on average equity are significant. These two coefficients have the expected signs: subsidiaries with owners that reside in expanding economies and that are more profitable expand their lending by more. The remaining owner-specific coefficients are insignificant. To interpret the estimated value for the GDP coefficient we can expand the above thought experiment as follows: assume that in addition to bank $x$ there is a bank $y$ in Brazil that is owned by a different IAB, say IAB $n$, that is located in a different country from the owner of bank $x$ (IAB $m$ ). Now assume that IAB $m$ 's economy experiences a 1 percent increase in its GDP growth rate while IAB $n$ 's does not, then the coefficient value of 1.323 implies that bank $x$ expands its lending by 1.323 percent more than bank $y$. A similar interpretation applies to the coefficient of ROAE. If IAB m's ROAE is 1 percent higher than IAB $n$ 's then bank $x$ increases its loan by 3.97 percent more than bank $y$. 


\subsection{Broader set of macroeconomic and bank-level indicators}

Our baseline macroeconomic and financial indicators give us a good way of identifying owner (IAB) and subsidiary-specific determinants of lending. As a robustness check, we use alternative country and bank level indicators to expand our set of macroeconomic variables and financial ratios and reinvestigate the relationships above. In expanding the set of macroeconomic variables, we mostly incorporate different interest rates to approximate the costs of funding and returns to lending. We choose not to expand the list of macroeconomic indicators related to borrowers' conditions since GDP and unemployment are the most com-

prehensive measures of economic activity that are directly related to borrower balance sheets and that are at the same time the most harmonized measures across the countries in our sample.

In Table 4, we report the coefficients of the macroeconomic variables in equation (7) and (9). These coefficient estimates have similar interpretations and, more generally, reveal that host-specific macroeconomic factors are more significant determinants of subsidiary lending than owner-specific macroeconomic factors. We do not report the control variable coefficients and the diagnostic test statistics in the table as they are qualitatively similar. The owner's GDP is the only owner-specific macroeconomic variable that has a significant effect on subsidiary lending. Turning to host-specific factors, we find that subsidiaries in countries with rising interest rates contract their lending more than their sister subsidiaries located in countries with relatively stable interest rates. This negative relationship can be due to both supply and demand factors. On the supply side, a rise in deposit rates can increase local funding costs, while an increase in T-Bill rates can negatively impact lending if banks are holding government securities. On the demand side, an increase in lending and money market rates can coincide with a drop in loan demand. The more central finding here, though, is that an increase in interest rates restricts lending only if this takes place in the host nation. In addition, we find that subsidiaries in countries with an appreciating currency and higher equity growth expand their lending by more. The former result is consistent with 
the findings of Bruno and Shin (2015b), who show that appreciating local currencies increase the perceived creditworthiness of local borrowers with currency mismatches on their balance sheets and, ultimately, lead to more lending to such borrowers.

Next, we broaden the set of financial ratios by including all ratios provided in the Bankscope database. These ratios are similarly categorized under the four groups (capital adequacy, asset quality, performance, liquidity) that we defined above and their definitions are provided in Appendix A. The results obtained by using these ratios in both equations (7) and (9) are displayed in Table 5. We report these results in four blocks corresponding to the four groups.

A majority of the owner and subsidiary-specific capital adequacy ratio coefficients are significant. All of the significant coefficients for both owners and subsidiaries have a positive sign suggesting that higher capitalization levels of owners or subsidiaries are associated with higher levels of lending by subsidiaries. While two of the standard regulatory measures of capital adequacy, i.e., the total (tier $1+$ tier 2 ) capital ratio and the tier 1 ratio, are insignificant in equation (9), the other measures are mostly significant. One difference between these two ratios and the remaining measures of capital adequacy is that the former are based on risk-weighted assets and they could be more binding than the latter. ${ }^{14}$ The insignificant coefficients for owners could then be a product of owners carrying excess capital and thus non-binding capital restrictions. ${ }^{15}$ This is a unique result as it offers a different perspective on the relationship between capital adequacy and lending behavior. The literature is divided on this subject, with studies such as Berrospide and Edge (2010), Hancock and Wilcox (1993) and Bernanke and Lown (1990), Francis and Osborne (2009) finding modest effects of capital on lending (especially for larger banks), and the findings in studies such as Adrian and Shin (2007), Hatzius (2007), Ciccarelli et al. (2010) and Gambacorta and Shin

\footnotetext{
${ }^{14}$ There is evidence that ratios based on risk-weighted assets tend to be more binding for some banks, while ratios based on total assets tend to be more binding for others (Brei and Gambacorta, 2016; Fender and Lewrick, 2015).

${ }^{15}$ There is also evidence indicating that the actual implementation of Basel rules is highly different across countries, making the stringency of capital restrictions non-uniform (e.g. Kara, 2016).
} 
(2016) implying otherwise. Our results suggest that the significance of large bank capital adequacy for lending behavior may vary by the type of ratio; while risk-weighted asset based ratios do not affect this behavior, those based on total assets do.

In contrast to the results for capital adequacy, we do not find that the liquidity ratios of owners and subsidiaries are equally significant determinants of lending and that subsidiaries' liquidity is more closely related to their lending than their owners' liquidity. In fact, we do not find a significant relationship for any of the owners' liquidity measures. The signs of the significant coefficients for the subsidiaries indicate that subsidiaries with more liquid assets expand their lending by more. ${ }^{16}$ Turning to the different performance and asset quality ratios, we again do not observe a clear difference in the significance of the owners' and subsidiaries' coefficients. These coefficients in general imply that higher asset quality and performance are associated with higher levels of lending. The coefficients of the performance ratios of both owners and subsidiaries, though, are not as significant as the coefficients of the ratios in the other three categories. There is a similar disparity between the standard deviations of these different ratios across owners and subsidiaries making it difficult to compare the magnitude of the coefficients to draw conclusions for economic significance.

\subsection{Pull-Push interaction terms}

Our baseline methodology that shuts off pull effects when measuring the impact of push factors and vice versa is effective only if there is no interaction between the two effects. In measuring pull effects, for example, if owner-specific variables, besides their symmetric effects on its subsidiaries' lending, affect the sensitivity of lending to subsidiary and hostnation specific variables then our baseline model needs to be expanded to account for this channel. This is what we do in this section. To incorporate pull-push interaction, we expand

\footnotetext{
${ }^{16}$ Notice here that an increase in the ratios with loans (the illiquid asset) in the numerator implies a decrease in liquidity.
} 
equations (7) and (9) as follows:

$$
\begin{aligned}
l d_{i j, t}^{h} & =\sum_{k=1}^{2} \lambda_{k}^{h} l d_{i j, t-k}^{h}+\gamma_{1}^{h} h f d_{i j, t-1}+\varphi_{1}^{h} h f d_{i j, t-1} \cdot o f d_{i j, t-1}+\sum_{m=1}^{M} \alpha_{m}^{h} o f_{j, t-1}^{m}+\varepsilon_{i j, t}^{h} \\
l d_{i j, t}^{l} & =\sum_{k=1}^{2} \lambda_{k}^{l} l d_{i j, t-k}^{l}+\gamma_{1}^{l} o f d_{i j, t-1}+\varphi_{1}^{l} o f d_{i j, t-1} \cdot h f d_{i j, t-1}+\sum_{m=1}^{M} \alpha_{m}^{l} h f_{i, t-1}^{m}+\varepsilon_{i j, t}^{l}
\end{aligned}
$$

where pull and push effects are measured in equations (10) and (11), respectively and the third term on the right hand side of each equation captures the pull-push interaction. We measure this interaction separately for each pair of our baseline owner/lender-nation and subsidiary/host-nation specific variables. When measuring pull effects due to a host nation's GDP in equation (10), for example, we interact this variable with the seven baseline owner/lender-nation specific variables (listed in the top row of Table 3) in separate estimations. We apply the same procedure when estimating equation (11).

Our results for equations (10) and (11) are reported in Tables 6 and 7, respectively. In Table 6, the signs and the significance of the pull factors are mostly similar in the extended model. There is one difference that should be noted. In estimations with lending-nation deposit rate interaction, the macroeconomic pull factors are all insignificant indicating that changes in the deposit rates in the lending-nation suppresses the sensitivity of IABs' subsidiaries to local macroeconomic factors. Turning to the coefficients of the interactive term, we observe that they are often insignificant (significant only in 8 estimations out of 49) and the interaction does not appear to attenuate pull effects. Moreover, in rare cases for which the interaction coefficients are significant, their relatively small magnitude suggests that the pull-push interaction is not as economically important as pull effects.

The general inference from Table 7 is similar. The coefficients of both macroeconomic and financial factors capturing push effects are mostly insignificant. The interactive term coefficients are again mostly insignificant albeit slightly more so compared to Table 6 (significant only in 10 equations out of 49). Overall, we find no evidence for significant and strong 
pull-push interaction in our estimations. ${ }^{17}$

\subsection{Sensitvity analyses}

Our sample includes countries for which we do not observe the currency composition of local claims in foreign currency, banks with cross-border lending yet only report their total loans, country pairs with a large number of IABs' subsidiaries, banks with M\&A activity, banks with different shares of lending and country pairs that are at different stages of development with different degrees of capital controls. In this section, we account for these characteristics.

\subsubsection{Excluding countries without currency decomposition of lending}

As mentioned above, there are 44 countries that report local claims in foreign currency (broken down by currency) to the BIS LBS. For the remaining countries in our sample, which tend to be countries with smaller economies and small shares of foreign currency lending, we assumed that all local lending is in local currencies. To test whether our results are sensitive to this assumption, we restrict our sample to the 44 countries that report to the BIS LBS (i.e. the countries for which the currency composition of claims is available). This allows us to match more closely our methodology with the data. The downside, of course, is that by doing so we are losing observations from the remaining 51 countries and we are, in effect, shifting our focus to the larger economies in the world.

The results that we obtain after applying this restriction are reported in the second column of Table 8. Compared to our baseline results, reproduced in the first column of the table for convenience, the magnitude of the GDP coefficient is larger for both owners and subsidiaries. Furthermore, the host nations' deposit rates are not significant determinants of lending in this restricted sample. The results for the financial ratios are more alike and similarly suggest a closer relationship between the subsidiaries' ratios and their lending. The insignificance of deposit rates signals that subsidiaries in larger economies may have a larger

\footnotetext{
${ }^{17}$ In alternative estimations, we omitted periods corresponding to the 2008 Global Financial Crisis and we similarly found no evidence for a strong pull-push interaction. These estimations results are available upon request.
} 
set of funding alternatives to local deposits compared to subsidiaries operating in smaller economies.

\subsubsection{Accounting for mergers and acquisitions}

So far, we have excluded loan growth rates that are above 200 percent and below -200 percent that can also reflect M\&A activity. In this section, we follow an alternative, and more rigorous way of identifying and excluding observations corresponding to M\&A activity. We do so by using the bank history information provided in the Bankscope database. Investigating this information, we manually identify 439 M\&A episodes. ${ }^{18}$ Following an M\&A, if a bank is absorbed by another bank it retains its identification number so that our time series observations of this bank are not disrupted. The assets and loans of this bank, however, typically change drastically (sometimes above and sometimes below the 200-percent threshold) confounding our analysis. We, therefore, exclude these periods from our estimations. The results reported in the third column of Table 8 are mostly similar to the baseline results in terms of signs and significance of the coefficients. With this restriction, however, the coefficients of macroeconomic indicators are larger and unemployment becomes significant in equation (9). The coefficients of the baseline financial ratios are again more significant for subsidiaries.

\subsubsection{Unadjusted loan growth rates}

As mentioned above, if the impact of currency fluctuations is not accounted for, the analysis of the relationship between loan growth rates and macroeconomic/financial conditions can potentially yield inaccurate results. To check whether controlling for exchange fluctuations has a significant impact on our results, we use unadjusted loan growth rates (implied by the raw Bankscope series on total loans) in our estimations. The results reported in the last set of columns in Table 8 indicate that while the significance and the signs of the coefficients are mostly the same, their sizes are considerably different. The magnitudes of the host-specific

\footnotetext{
${ }^{18}$ In our list of M\&A's there are banks with multiple (up to 4 times) observations during the sample period.
} 
macroeconomic variables, for example, are considerably larger while the GDP coefficient for the lending nation is much smaller. By contrast, we observe that the subsidiary financial ratio coefficients are not as large.

The above results can be interpreted as evidence for the importance of adjusting loan growth rates for exchange rate fluctuations. While the qualitative inferences are the same, one can draw starkly different quantitative conclusions from estimations in which the growth rates of loans are not adjusted for exchange rate fluctuations.

\subsubsection{Accounting for cross-border lending}

The lending data reported in Bankscope cover total loans, which tend to consist primarily of loans to local residents, but may also include cross-border lending. Unfortunately, there is no way of determining the fraction of cross-border lending at the bank level since the Bankscope database does not contain such breakdowns. Nevertheless, the BIS IBS offer a way to account for these loans at the country level. Specifically, BIS LBS and BIS CBS, which are available on a bilateral basis, can be combined to produce estimates of the fraction of claims extended by banks of a given nationality located in a given host country (e.g. French banks in Turkey) that are booked locally.

We use the above statistics to construct a time series of local lending shares for each pair of countries in our full sample. After doing so, we restrict/adjust our dataset in two ways. First, we re-estimate our regressions after excluding (nationality/location) country pairs for which the share of cross-border lending by local banks exceeds 25 percent. ${ }^{19}$ The results corresponding to this restriction are reported in the second set of columns in Table 9. The magnitudes and the significance of the coefficients are similar to the baseline results reported in the first set of columns. The only exceptions are the deposit rate coefficients in equations (7) and (9), which are more significant and larger than in the baseline estimation, and the owner performance coefficient, which is no longer significant.

\footnotetext{
${ }^{19}$ We obtain qualitatively similar results when we use lower (i.e., more conservative shares). Nevertheless, using lower shares, (for example 10 percent) reduces the number of observations considerably.
} 
Second, we account for the share of cross-border lending more rigorously by applying these shares to the bank-level data. More concretely, we assume that, at each point in time, the share of locally-extended loans in total loans for a bank of nationality $a$ located in host country $b$ is equal to the estimate for the respective share for the (nationality/location) country pair $a-b$, obtained from BIS LBS and BIS CBS, using the methodology described above. To approximate the volume of loans that are extended locally by each bank of nationality $a$ located in host country $b$, we multiply total loans of that bank (obtained from Bankscope) by the local-loans share for the (nationality/location) country pair $a-b$ (obtained using the BIS IBS estimate). We then compute growth rates of local lending, adjusted for exchange rate fluctuations, by using the share of total loans.

Due to the fact that some of the 44 countries which submit data to the BIS LBS join the reporting population after the start of our sample, the BIS panel with shares of cross-border lending is unbalanced, with missing observations for some country pairs and time periods. That is why, before applying the methodology described above, we only focus on periods with two consecutive positive observations of cross-border shares. This ensures that our computation does not produce artificially low values.

The results obtained for this specification of the dependent variable are reported in the third set of columns of Table 9 . These are mostly similar to our baseline results. Nevertheless, there are some exceptions. First, subsidiaries' lending is more sensitive to GDP (especially to the GDP of their parents). Second, unemployment in the host nation and the performance of the parent IAB are no longer significant determinants of lending. Finally, the magnitudes of the subsidiary financial ratio coefficients are also larger compared to our baseline results.

To summarize, the overall evidence from the set of robustness checks is consistent with our main conclusions. Furthermore, it is also revealed that, when the data are purged of crossborder lending, the link between lending behavior and the independent variables strengthens, as demonstrated by the larger and more statistically significant coefficient estimates.

So far, we purged lending data by taking out the cross-border component to hone in on 
local lending. Next, we go in the opposite direction and focus on this purged component. Specifically, for each subsidiary we subtract their lending growth net of cross-border lending from their total lending growth. The product of this operation is a variable that approximates the relative growth of cross-border funds (directed to lending) that a given subsidiary allocates abroad. This exercise allows us to determine whether cross-border lending is related to pull and push factors and thus to indirectly infer whether there is any interaction between local and cross-border lending when push and pull factors change.

Using the bank-level cross-border lending growth data as our dependent variable in equations (7) and (9) produces the results displayed in the fourth set of columns in Table 9. According to these results cross-border lending is not sensitive to pull factors with the exception of local deposit rates. By contrast, the push factors, lending nation's GDP and unemployment, and the liquidity of IABs are significant determinants of cross-border lending. The signs of these coefficients indicate that cross-border lending decreases if lending-nations' GDP grows faster, unemployment drops or the liquidity of IABs decreases. A possible explanation for these findings is that cross-border lending of subsidiaries may be more heavily funded through their IAB parents, which in turn may reallocate these funds from their overseas subsidiaries to the parent bank / headquarter when macroeconomic conditions improve. Conversely, an increase in the liquidity of the IAB parent may increase intra-group funding, which would in turn boost subsidiaries' cross-border lending.

\subsubsection{Accounting for the number of banks}

A distinct feature of our analysis is that we are controlling for currency fluctuations by using currency decomposition of lending. Currency decompositions, however, are only available (bilaterally) at the country level. Therefore, our implicit assumption is that the countrylevel decompositions also represent bank-level decompositions of loans by currency. While a majority of the country pairs in our sample have either a single or a small number of IAB subsidiaries, there are pairs (especially where both countries are large advanced economies) for which the number of subsidiaries is in the double-digits. For these countries then our 
assumption becomes less realistic, as different banks may have different currency baskets. To determine whether this feature of the data changes our results, we only include country pairs with less than five banks. ${ }^{20}$

The results from this alternative estimation are reported in the last set of columns in Table 9. Similar to our results obtained by controlling for cross-border lending, we find a stronger link between BHC and subsidiary-specific factors (especially for deposit rates) and lending in these estimations. Specifically, the coefficients have similar signs and are generally larger in magnitude.

We should note that the closer link that we find when we control for the number of banks may be a product of the set of countries that remain in our sample. This is also true for our first methodology that controls for cross-border lending. Specifically, the country pairs with a smaller number of banks typically consist of one large (host) economy and one small (home) economy. It is, therefore, possible that there may be more than one factor causing this closer link such as the degree of competition, the shares of foreign currency and cross-border lending.

\subsubsection{Accounting for lending shares}

Subsidiaries with different market shares may have different sensitivity to pull and push factors. It is possible, for example, that a subsidiary with a large lending share in a country may have a large impact on the returns to lending in that country and thus may be more reluctant to alter lending in response to changes in pull factors. If this large subsidiary can also raise funding independently, the support it receives from its parent may be less important compared to a smaller bank. These mechanisms could affect the impact of pull and push factors. However, banks with a large share in a given economy could also be more vulnerable/sensitive to local conditions and they may be subject to more control from their parent IABs given their size. Conversely, these would reinforce pull and push effects.

\footnotetext{
${ }^{20}$ We choose 5 as our cutoff point since in our bilateral panel, if we exclude the observations on the diagonal, the average number of banks was 5.24. We did, however, experiment with different cutoff values and obtained similar results.
} 
In this section we examine the above channels indirectly by extending our models to include subsidiaries' lending shares in a given country, measured as the ratio of a subsidiary's lending in a given country to the total lending by our sample banks in this country. We do so by including banks' lending shares as time-varying sample weights such that a subsidiary with a large share receives a higher weight in our estimations. ${ }^{21}$

Our results are reported in the second set of columns of Table 10. The signs and significance of the coefficients are similar to their baseline counterparts in columns 1 and 2 and similarly indicate that pull effects may be more important. The exceptions are that subsidiaries' asset quality and lending nation's GDP are no longer significant in equations (7) and (9), respectively, and that the liquidity of IABs is now significant in equation (9). The more central finding here is that the magnitudes of the significant coefficients in equation (7) tend to be much larger. This finding is consistent with the second mechanism mentioned above as it indicates that a subsidiary's lending is more sensitive to its financial condition and that of the economy where it operates when it has a large lending share in this economy.

\subsubsection{Accounting for proximity and economic development}

In our benchmark specification, we implicitly assume that internal capital markets operate similarly across subsidiaries irrespective of how far the subsidiary is located from its parent IAB. In addition, we do not distinguish between host nations and lending nations based on their economic development. It is possible, however, that internal capital markets operate differently when the parent IAB and the subsidiary are close to each other (e.g., a German IAB with a French subsidiary). It is also possible that the lending growth disparity between developing and advanced economies may be related to factors other than pull and push and the relative efficiency of internal capital markets in these two types of economies.

In this section, we investigate the effects of distance between nations and their economic

\footnotetext{
${ }^{21}$ We use the command pweight=1/lending_share in STATA to incorporate sample weights. Pweights represent the inverse probability that the observation is included in the sample. The command above, therefore, instructs STATA to estimate a version of our model where it is more populated by subsidiaries with higher lending shares. We use a similar strategy in several other tests below.
} 
development, proxied by income per capita, on our results. To do so, we utilize the square gravity dataset of Head et al. (2010). We merge this dataset with ours by including the distances between country pairs and the income per capita of nations. The distance variable is from the Centre d'Études Prospectives et d'Informations Internationales (CEPII) database and it measures the population-weighted great circle distance between large cities of two countries. The source for the income per capita data (GDP per capita in US Dollars) is from World Bank's World Development Indicators (WDI). We use the average value of GDP per capita during the sample period to measure the level of economic development.

We incorporate the above data into our analysis by using them as sample weights. We do this for consistency since distance does not vary across time and it cannot be incorporated as an independent variable in our dynamic panel model. In estimating equation (7) subsidiaryIAB pairs that are farther apart and host-nations with higher economic development receive a lower sampling weight. ${ }^{22}$ Distance weights are similar in equation (9) but this time lending nations with higher economic development are assigned lower weights. We do this to test whether pull and push effects are stronger for developing countries and for county pairs that are closer to each other.

The last two sets of columns in Table 10 display our results. The overall conclusion is that accounting for distance and income per capita yields similar results. There are few exceptions however. When we account for distance, for example, asset quality of the subsidiary in equation (7) and the performance of IABs in equation (9) are no longer significant. The larger magnitude of the GDP coefficient for equation (9) indicates that push effects may be stronger for countries closer to each other. When we account for economic development, unemployment in equation (7), in addition to asset quality, becomes insignificant.

\footnotetext{
${ }^{22}$ In alternative estimations, we gave higher sampling weights to developed economies and obtained similar results.
} 


\subsubsection{Accounting for capital controls}

So far we implicitly assumed that there are no restrictions on the flows of capital in and out of countries. Nevertheless, as shown by Fernández et al. (2016), there is not only a significant degree of restrictions on the inflows and outflows of capital but there is also significant variation in these restrictions both across countries and over time. This is potentially a key omission since our methodology assumes that the internal capital markets of IABs operate unimpeded across countries. It is, therefore, important to determine how the presence of capital controls affects our comparison of pull and push effects.

To incorporate capital controls into our analysis, we use data from Fernández et al. (2016). The data are available for all countries in our sample and consist of indices for the degree of restrictions on inflows and outflows of capital for the 1995-2015 period (at an annual frequency). Higher values of the index indicate higher levels of capital controls.

We include the growth rate of the capital inflow index and the capital outflow index on the right hand side of equations (7) and (9), respectively. In equation (7), where our focus is on the relative lending growth of IAB subsidiaries in different countries, we use the index capturing restrictions on capital inflows. Conversely, we use restrictions on capital outflows in equation (9), since our main focus in that specification is on flows from the headquarters of the IAB to its subsidiaries (capital outflows from the home country of IABs).

We estimate the models described above for all of our baseline pull and push variables. The results are displayed in Table $11 .{ }^{23}$ For equation (7), the signs and significance of the coefficients of pull factors are similar to our baseline results for every variable except GDP. Unlike our baseline estimations of equation (9) that revealed two significant push factors (out of seven), none of the push factors are significant. Overall, our results imply that while pull effects mostly remain when we account for capital controls, push effects diminish. ${ }^{24}$

\footnotetext{
${ }^{23}$ For brevity we omit the control variable coefficients from the table since they were similarly insignificant for the most part. The diagnostic statistics also did not reveal any evidence for second-order serial correlation in the error term or any evidence for the invalidity of the instruments.

${ }^{24}$ Inferences were similar when we used the remaining pull and push variables in our dataset. The significant coefficients on the capital restrictions variable were all positive. While this is true for each
} 
The novel finding here is that the coefficients of capital controls are all positive and significant in each estimation except one (equation (9) with deposit rates). The positive coefficients imply that if a country has a higher restriction on capital inflows, the subsidiary of an IAB residing in this country increases its lending growth by more than its sister subsidiaries in other countries. A more refined analysis, beyond the scope of this paper, would be required to determine the reasons for this outcome. We can however project that the subsidiary could be lending more due to a lower degree of market saturation that results from the inflow restrictions.

The positive push factor coefficients imply that a subsidiary whose parent becomes subject to outflow restrictions lends relatively more. A potential explanation of this result could be as follows: since its ability to do direct cross-border lending would be impaired by outflow restrictions, IABs substitute this with their subsidiaries' lending. As the financial ratios of IABs improve, for example, it could decrease the amount of funds it withdraws/requires from its subsidiaries to cross-subsidize them.

\subsubsection{Additional sensitivity analyses}

We perfomed three additional tests. First, we used a specification for the main independent variables that is different from the deviational form described above. Second, we reconstructed our dataset with country-level data. Finally, we used total assets as weights when constructing our main dependent variables. All of these tests, discussed in Appendix B, pointed to a similar disparity between pull and push effects.

\subsection{Economic significance}

So far, our results indicate that subsidiary lending is more closely related to local macroeconomic variables. For some of the financial ratios in our analysis we do not observe a similar disparity between the statistical significance of subsidiary and owner-specific coefficients. In this section, we compare the relative importance of subsidiary and owner-specific

equation, the number of significant capital restriction coefficients were larger in our estimations of equation (9). 
financial ratios for local bank lending. As mentioned above, comparing the magnitudes of the coefficient estimates in our baseline regressions does not allow us to make this assessment accurately as the two types of variables have different degrees of variation. In particular, we observe that the standard deviation of host nation and subsidiary-specific variables is higher. To adjust for this difference in variations, we rescale our main independent variables in equations (7) and (9) and divide them by their sample standard deviations. We then compare the economic significance of these two sets of variables.

Table 12 makes this comparison only for the ratios that had significant coefficients in both equation (7) and (9). For all the coefficient pairs that we report in this table, equation (7) coefficients are larger in magnitude suggesting that a subsidiary's financial condition/structure is a more important determinant of its lending behavior than its parent's financial condition/structure. While the fact that the differences in some of the ratio coefficients are not large qualifies this conclusion, we should note that for a majority of the ratios (especially for the liquidity ratios) that we did not compare in this sub-section, subsidiary ratios had significant coefficients and owner ratios did not. ${ }^{25}$

\section{Conclusion}

Our analysis in this paper sheds new light on the role of global banks in the international transmission of macroeconomic and financial shocks. A common agreement in the existing literature on the subject is that global banks play a major role in determining capital flows by transmitting the shocks they face to the countries that they lend in. These so-called push factors do a good job of explaining the spillover effects of the 2008 crisis and the subsequent recovery in open economy models. Empirical evidence is generally consistent with theoretical predictions.

In our paper, we investigate the pull as well as the push determinants of global bank

\footnotetext{
${ }^{25}$ We replicated this methodology for all of our sensitivity analyses. While the results were similar qualitatively, we found a larger disparity (larger coefficients of the subsidiary-specific variables) when we used our alternative way of accounting for M\&A activity.
} 
lending and allow for a horse-race between the two. Our results demonstrate that pull (host nation and subsidiary-specific) factors are more important determinants of global bank lending than push (lending nation and owner bank holding company specific) factors. Specifically, the results show that the macroeconomic conditions in the country in which the subsidiaries of global banks reside and the financial condition of these subsidiaries are both statistically and economically more important for their lending behavior compared to the macroeconomic conditions in their owners' countries and their owners' financial condition. We obtain these results by using bank-level data, BIS locational and consolidated banking statistics to account for the currency decomposition of global banks' loans and their cross-border lending, and a unique methodology to identify the independent effects of push and pull factors. The strength of our conclusions comes from a large set of tests that demonstrate robustness.

This paper makes predictions for the determinants, but not the macroeconomic effects of global bank lending. Our predictions though should inform future research on the effects of global bank lending. There are two well-known mechanisms in the global banking literature that can potentially (de)stabilize economies: the support mechanism (parent banks' provision of loanable funds through internal capital markets) and the substitution mechanism (reallocation of loans across countries to equate risk-adjusted returns). Our findings suggest that the substitution mechanism of global banking is more important than the support mechanism and that it should receive greater attention when assessing the macroeconomic impact of global banking.

Our paper also provides insights for the relative importance of centralized versus decentralized decision making in global banking. Specifically, we show that the lending behavior of subsidiaries of global banks is more strongly linked to their own financial condition compared to their owners' financial condition and that local funding costs have a significant impact on their lending. These results suggest that decentralized decision-making may be more prevalent in global banking. It would be interesting to directly test this hypothesis by using bank-level data on banking flows through internal capital markets. One could determine how 
these flows are related to actual lending behavior of subsidiaries and draw direct inferences for the relative strength of centralized versus decentralized decision making (as well as pull versus push factors) in global banking. ${ }^{26}$

\section{References}

[1] Adrian, T., and H. S. Shin (2007). "Liquidity and Leverage," Mimeo, Princeton, NJ.

[2] Allen, F., T. Beck, E. Carletti, P.R. Lane, D. Schoenmaker and W. Wagner (2011) "Cross-Border Banking in Europe: Implications for Financial Stability and Macroeconomic Policies", CEPR Report.

[3] Alpanda, S., and U. Aysun (2014). "International transmission of financial shocks in an estimated DSGE model," Journal of International Money and Finance, 47, 21-55.

[4] Arellano, M., and O. Bover (1995). "Another look at instrumental variables estimation of error-component models," Journal of Econometrics, 68, 29-51.

[5] Ashcraft, A., and M. Campello (2007). "Firm Balance Sheets and Monetary Policy Transmission," Journal of Monetary Economics, 54, 1515-1528.

[6] Avdjiev S., and E. Takáts (2014). "Cross-border bank lending during the taper tantrum: the role of emerging markets fundamentals", BIS Quarterly Review, September.

$[7]$ in cross-border bank lending" Bank for International Settlements, Working Paper 549.

[8] Avdjiev, S., R. McCauley and P. McGuire (2012). "Rapid credit growth and international credit: challenges for Asia", in V Pontines and R Siregar (eds), Exchange rate appreciation, capital flows and excess liquidity: adjustment and effectiveness of policy responses, The SEACEN Centre, August, pp 215-44.

[9] Aysun, U., and R. Hepp (2011). "Securitization and the Balance Sheet Channel of Monetary Transmission," Journal of Banking and Finance, 35(8), 2111-2122.

[10] (2013). "Identifying the balance sheet and lending channels of monetary transmission: A loan-level analysis," Journal of Banking and Finance, $37(8), 2812-2822$.

[11] (2016). "The determinants of global bank lending: Evidence from bilateral cross-country data," Journal of Banking and Finance, 66, 35-52.

[12] Bernanke, B., and C. Lown (1991). "The Credit Crunch," Brookings Papers on Economic Activity 2, 205-247.

[13] Berrospide, J.M., and R. M. Edge (2010). "The Effects of Bank Capital on Lending: What Do We Know, and What Does it Mean?", Federal Reserve Board Finance and Economics Discussion Series, No: 2010-44.

[14] Brei M. and L. Gambacorta (2016). "Are bank capital ratios pro-cyclical? New evidence and perspectives," Economic Policy, 31(86), 357-453.

\footnotetext{
${ }^{26}$ Buch et al. (2016) provides an example for the type of data that could be useful for this analysis.
} 
[15] Bruno V., and H.S. Shin (2015a). "Cross-Border Banking and Global Liquidity," Review of Economic Studies, 82 (2), 535-564.

[16] Monetary Policy", Journal of Monetary Economics 71: 119-132

[17] Buch, C.M. (2000). "Why Do Banks Go Abroad? Evidence from German Data," Financial Markets, Institutions and Instruments, 9, 33-67.

[18] Buch, C., C. Koch, and M. Koetter (2016). "Crises and rescues: liquidity transmission through international banks," Bank for International Settlements, Working Paper, 576.

[19] Campello, M. (2002). "Internal capital markets in financial conglomerates: Evidence from small bank responses to monetary policy," Journal of Finance, 57, 2773-2805.

[20] Cecchetti, S, I. Fender, P. McGuire (2010) "Toward a global risk map" BIS WP 309.

[21] Cerutti, E.M. and S. Claessens (2016) "The Great Cross-Border Bank Deleveraging: Supply Constraints and Intra-Group Frictions," Review of Finance, 21(1), 201-236.

[22] Cerutti, E.M., S. Claessens and D. Puy (2015). "Push Factors and Capital Flows to Emerging markets: Why Knowing Your Lender Matters More Than Fundamentals," IMF Working Paper 15/127.

[23] Cerutti, E.M. and S. Claessens and L. Ravnotski (2016). "Global Liquidity and CrossBorder Banking Flows," Economic Policy, forthcoming.

[24] Cerutti, E.M., S Claessens and A K Rose (2017), "How important is the financial cycle? Evidence from capital flows", BIS Working Papers 661.

[25] Cetorelli N, L Goldberg (2012a) "Liquidity management of US Global Banks:Internal Capital Markets in the Great Recession" Journal of International Economics 88, 299311.

[26] (2012b). "Banking Globalization and Monetary Transmission," Journal of Finance 67(5), 1811-1843.

[27] (2016). "Organizational complexity and balance sheet management in global banks," Staff Reports 772, Federal Reserve Bank of New York.

[28] Ciccarelli, M., A. Maddaloni, and J-L. Peydro-Alcalde (2010). "Trusting the Bankers: Another Look at the Credit Channel of Monetary Policy." Mimeo, Frankfurt, Germany.

[29] Claessens, S. (2017). "Global Banking: Recent Developments and Insights from Research," Review of Finance, 21(4), 1513-1555.

[30] Crystal, J.S., B. Dages, and L.S. Goldberg (2002). "Has foreign bank entry led to sounder banks in Latin America?" Federal Reserve Bank of New York, Current Issues in Economics and Finance, 8(1).

[31] Dages, B.G., L.S. Goldberg, and D. Kinney (2000). "Foreign and Domestic Bank Participation in Emerging Markets: Lessons from Mexico and Argentina," Federal Reserve Bank of New York Economic Policy Review, 6(3), 17-36.

[32] Dahl, D., R. E. Shrieves, and M. F. Spivey (2002). "Financing Loan Growth at Banks," Journal of Financial Services Research, 22, 189-202. 
[33] De Haas, R., and N. van Horen, (2013). "Running for the Exit? International Bank Lending During a Financial Crisis," Review of Financial Studies, 26(1), 244-85.

[34] De Haas, R., I. Van Lelyveld (2006). "Foreign Banks and Credit Stability in Central and Eastern Europe. A Panel Data Analysis," Journal of Banking and Finance, 30, 1927-52.

[35] _ (2010). "Internal capital markets and lending by multinational bank subsidiaries," Journal of Financial Intermediation, 19, 1-25.

[36] Fender I and U Lewrick (2015) "Calibrating the leverage ratio" BIS Quarterly Review, December, $43-58$.

[37] Fender, I., P McGuire (2010) "Bank structure, funding risk and the transmission of shocks across countries:concepts and measurement" BIS Quarterly Review Sep, 63-79.

[38] Fernández, A., M.W. Klein, A. Rebucci, M. Schindler and M. Uribe (2016) "Capital Control Measures: A New Dataset" IMF Economic Review, 64(3), 548-574.

[39] Fiechter J, Ötker-Robe I, Ilyna A, Hsu M, Santos A, and Jay Surti (2011) "Subsidiaries or Branches: Does One Size Fit All?", IMF Staff Discussion Note, March.

[40] Forbes, K. and F.E. Warnock. (2012). "Capital Flow Waves: Surges, Stops, Flight, and Retrenchment," Journal of International Economics, 88(2), 235-251.

[41] Francis, W., and M. Obsorne (2009). "Bank Regulation, Capital and Credit Supply: Measuring the Impact of Prudential Standards." Occasional Paper No: 36, UK Financial Services Authority, London, UK.

[42] Fratzscher, M. (2012). "Capital flows, push versus pull factors and the global financial crisis," Journal of International Economics, 88(2), 341-356.

[43] Gambacorta, L., and H.S. Shin (2016). "Why bank capital matters for monetary policy," Bank for International Settlements, Working Paper No 558, April.

[44] Gertler, M., and P. Karadi (2011). "A Model of Unconventional Monetary Policy," Journal of Monetary Economics, 58, 17-34.

[45] Goldberg, L.S. (2002). "When Is U.S. Bank Lending to Emerging Markets Volatile?" in Preventing Currency Crises in Emerging Markets, ed. S. Edwards and J. A. Frankel, 171-196. Boston: NBER.

[46] Hancock, D., and J. Wilcox (1993). "Has There Been a 'Capital Crunch' in Banking? The Effects on Bank Lending of Real Estate Market Conditions and Bank Capital Shortfalls," Journal of Housing Economics 3, 31-50.

[47] Hatzius, J. (2007). "Leveraged Losses: Why Mortgage Defaults Matter," Goldman Sachs U.S. Daily, November 15, 2007.

[48] Head, K., T. Mayer and J. Ries (2010) "The erosion of colonial trade linkages after independence" Journal of International Economics, 81(1), 1-14.

[49] Hernandez, L., and H. Rudolph (1995). "Sustainability of private capital flows to developing countries," World Bank Policy Research Working Paper 1518.

[50] Houston, J.F., Lin, C., Ma, Y., (2012). "Regulatory Arbitrage and International Bank Flows." The Journal of Finance 67, 1845-1895. 
[51] Houston, J., D. Marcus, and C. James (1997). "Capital market frictions and the role of internal capital markets in banking," Journal of Financial Economics, 46, 135-164.

[52] Jeanneau, S., M. Micu (2002). "Determinants of International Bank Lending to Emerging Market Countries," Bank for International Settlements, Working Paper, 112.

[53] Jiménez G., Lopez, J.A., Saurina, J. (2009). "Empirical analysis of corporate credit lines," Review of Financial Studies 22, 5069-5098.

[54] Kara, G. I. (2016). "Bank Capital Regulations Around the World: What Explains the Differences?," Finance and Economics Discussion Series 2016-057. Washington: Board of Governors of the Federal Reserve System (U.S.).

[55] Koepke, R. (2015). "What Drives Capital Flows to Emerging Markets? A Survey of the Empirical Literature," MPRA Paper 62770, University Library of Munich, Germany.

[56] Kollmann, R (2013) "Global Banks, Financial Shocks and International Business Cycles: Evidence from an Estimated Model" Journal of Money, Credit and Banking 45,159-95.

[57] Kollmann, R., Z. Enders, and G. Muller (2011). "Global banking and international business cycles," European Economic Review, 55, 407-426.

[58] Martinez Peria, M.S., A. Powell, and I.V. Hollar (2002). "Banking on Foreigners: The Behavior of International Bank Lending to Latin America, 1985-2000," World Bank Policy Research Working Paper No. 2893.

[59] Meh, C., and K. Moran (2010). "The Role of Bank Capital in the Propagation of Shocks," Journal of Economic Dynamics and Control, 34, 555-576.

[60] Miranda-Agrippino, S. and H. Rey (2015). "World Asset Markets and the Global Financial Cycle," NBER Working Paper No. 21722.

[61] Morgan, D. P., P.E. Strahan (2004). "Foreign Bank Entry and Business Volatility: Evidence from U.S. States and Other Countries," in Foreign Banking Market Structure and Monetary Policy, ed. Luis Ahumada and J. Fuentes. Santiago:Central Bank of Chile.

[62] Obstfeld, M. (2012). "Does the Current Account Still Matter?", American Economic Review, 102(3), 1-23.

[63] Ongena, S., J. L. Peydro, and N. van Horen (2013) "Shocks Abroad, Pain at Home? Bank-firm Level Evidence on Financial Contagion During the 2007-2009 Crisis," De Nederlandsche Bank, Working Paper 385.

[64] Peek, J., and E.S. Rosengren (2000). "Collateral damage: Effects of the Japanese bank crisis on the United States," American Economic Review, 90, 30-45.

[65] Rey, H. (2015). "Dilemma not Trilemma: The global Financial Cycle and Monetary Policy Independence," National Bureau of Economic Research Working Paper No: 21162.

[66] Roodman, D. (2009). ""How to do xtabond2: An introduction to difference and system GMM in Stata," Stata Journal, 9(1), 86-136.

[67] Schnabl, P. (2012). "International Transmission of Bank Liquidity Shocks: Evidence from an Emerging Market," Journal of Finance 67, 897-932.

[68] Shin, H. S. (2012). "Global Banking Glut and Loan Risk Premium," Mundell-Fleming Lecture, IMF Economic Review 60 (2), 155-192. 


\section{Appendix A. Data}

Table A.1. Data definitions

\begin{tabular}{|c|c|}
\hline Variables & Description \\
\hline $\begin{array}{l}\text { Loans } \\
\text { Capital adequacy ratios }\end{array}$ & Total loans \\
\hline Total Capital Ratio & $\begin{array}{l}\text { Tier } 1+\text { Tier } 2 \text { capital (including subordinated debt, hybrid capital, loan loss reserves and valuation reserves) as a share of risk } \\
\text { weighted assets and off balance sheet risks. }\end{array}$ \\
\hline Tier 1 Ratio & Tier 1 capital (shareholder funds plus perpetual non cumulative preference shares) / risk weighted assets \& off balance sheet risks. \\
\hline Equity / Tot Assets & This ratio measures the amount of protection afforded to the bank by the equity they invested in it. The higher values indicate \\
\hline Equity / Net Loans & This ratio measures the equity cushion available to absord losses on the loan book. \\
\hline Equity / Cust \& ST Funding & The amount of permanent funding relative to short term potentially volatile funding. \\
\hline Equity / Liabilities & This leverage ratio is simply another way of looking at the equity funding of the balance sheet and capital adequacy. \\
\hline Cap Funds / Tot Assets & (Equity + hybrid capital + subordinated debts) $/$ total assets \\
\hline Cap Funds / Net Loans & (Equity + hybrid capital + subordinated debts) / net loans \\
\hline Cap Funds / Dep \& ST & (Equity + hybrid capital + subordinated debts) $/$ Deposits \& Short term funding \\
\hline Cap Funds / Liabilities & (Equity + hybrid capital + subordinated debts) / total liabilities \\
\hline Subord Debt / Cap Funds & The percentage of total capital funds provided in the form of subordinated debt. \\
\hline \multicolumn{2}{|l|}{ Performance ratios } \\
\hline Net Interest Margin & Net interest income to earning assets. The higher this figure the cheaper the funding or the higher the margin. \\
\hline Net Int Rev / Avg Assets & This ratio is similar to the net interest margin but it is expressed as a percentage of the total balance sheet. \\
\hline Oth Op Inc / Avg Assets & This ratio indicates to what extent fees and other income represent a greater percentage of earnings of the bank. \\
\hline Non Int Exp / Avg Assets & Non interest expenses or overheads plus provisions. It measures the costs relative to the assets invested. \\
\hline Pre-Tax Op Inc / Avg Assets & This is a measure of the operating performance of the bank before tax and unusual items. \\
\hline Non Op Items \& Taxes / Avg & This ratio measures costs and tax as a percentage of assets. \\
\hline Return On Avg Assets & The returns generated from the assets financed by the bank. \\
\hline Return On Avg Equity & Measures the return on shareholder funds. \\
\hline Dividend Pay-Out & Measures the share of post tax profits paid out to shareholders. \\
\hline Inc Net Of Dist / Avg Equity & The return on equity after deducting the dividends from returns. The increase in equity due to internally generated funds. \\
\hline Non Op Items / Net Income & The percentage of total net income consisting of unusual items. \\
\hline Cost To Income Ratio & The overhead costs of running the bank as percentage of income generated before provisions. \\
\hline \multicolumn{2}{|l|}{ Asset quality ratios } \\
\hline$\overline{\text { Loan Loss Res / Gross Loans }}$ & Indicates how much of the total portfolio has been provided for but not charged off. It is a reserve for losses (\% of total loans). \\
\hline Loan Loss Prov / Net Int Rev & Provisions in the profit and loss account to interest income. \\
\hline Loan Loss Res / Impair. & Loan loss reserves to nonperforming or impaired loans. \\
\hline Impaired Loans / Gross Loans & This is a measure of the amount of total loans which are doubtful. \\
\hline NCO / Average Gross Loans & Net charge offs or the amount written-off from loan loss reserves less recoveries as a percentage of the gross loans. \\
\hline NCO / Net Inc Bef Ln Lss & Net charge offs to income net of loan loss provisions \\
\hline Impaired Loans / Equity & Impaired or problem loans as a percentage of the bank s equity. \\
\hline Unres. Impair. Loans / Equity & Impaired or problem loans not covered by reserves, as a percentage of capital. \\
\hline \multicolumn{2}{|l|}{ Liquidity ratios } \\
\hline Interbank Ratio & Loans to other banks divided by funds borrowed from other banks. \\
\hline Net Loans / Tot Assets & The percentage of assets constituting loans. \\
\hline Net Loans / Dep \& ST & Loans to deposits and short term funding. \\
\hline Net Loans / Tot Dep \& Bor & Similar to the ratio above except the denominator includes deposits and total borrowing \\
\hline $\begin{array}{l}\text { Liquid Assets / Dep \& ST } \\
\text { Funding }\end{array}$ & The percentage of customer and short term funds that could be serviced if they are withdrawn immediately. \\
\hline $\begin{array}{l}\text { Liquid Assets / Total Debt } \\
\text { and Borr. }\end{array}$ & This ratios is similar to the one above but the denominator includes total borrowing. \\
\hline \multicolumn{2}{|l|}{ Macroeconomic variables } \\
\hline GDP & Gross Domestic Product by Expenditure in Constant Prices. Seasonally adjusted index, $2010=1$. \\
\hline Unemployment & Harmonized unemployment rate. All Persons, seasonally adjusted. \\
\hline Exchange rate & Annual average and end of period nominal exchange rates expressed as US Dollars per currency. \\
\hline Deposit rate & $\begin{array}{l}\text { Rates offered to resident customers for demand, time, or savings deposits. The rates for time and savings deposits are classified } \\
\text { according to maturity and amounts deposited. Deposit money banks and similar deposit-taking institutions may offer short and } \\
\text { medium-term instruments at specified rates for specific amounts and maturities; i.e. "certificates of deposit." }\end{array}$ \\
\hline Lending rate & $\begin{array}{l}\text { The bank rate that usually meets the short- and medium-term financing needs of the private sector. This rate is normally } \\
\text { differentiated according to creditworthiness of borrowers and objectives of financing. }\end{array}$ \\
\hline Money market rate & The rate on short-term lending between financial institutions. \\
\hline T-Bill rate & The rate at which short-term securities are issued or traded in the market. \\
\hline Central bank policy rate & The rate at which the central banks lend or discount eligible paper for deposit money banks \\
\hline Equity & Annual index of share prices \\
\hline \multicolumn{2}{|l|}{ Bilateral data } \\
\hline Currency decomposition & BIS locational banking statistics, currency decomposition of local claims in foreign currency \\
\hline Share of cross-border lending & BIS locational banking statistics, share of local claims in total claims \\
\hline Number of reporting banks & BIS locational statistics, number of reporting banks for each country pair \\
\hline
\end{tabular}


Appendix B. Additional sensitivity analyses

Available online: insert url

Figure 1. Growing share of local claims in foreign claims

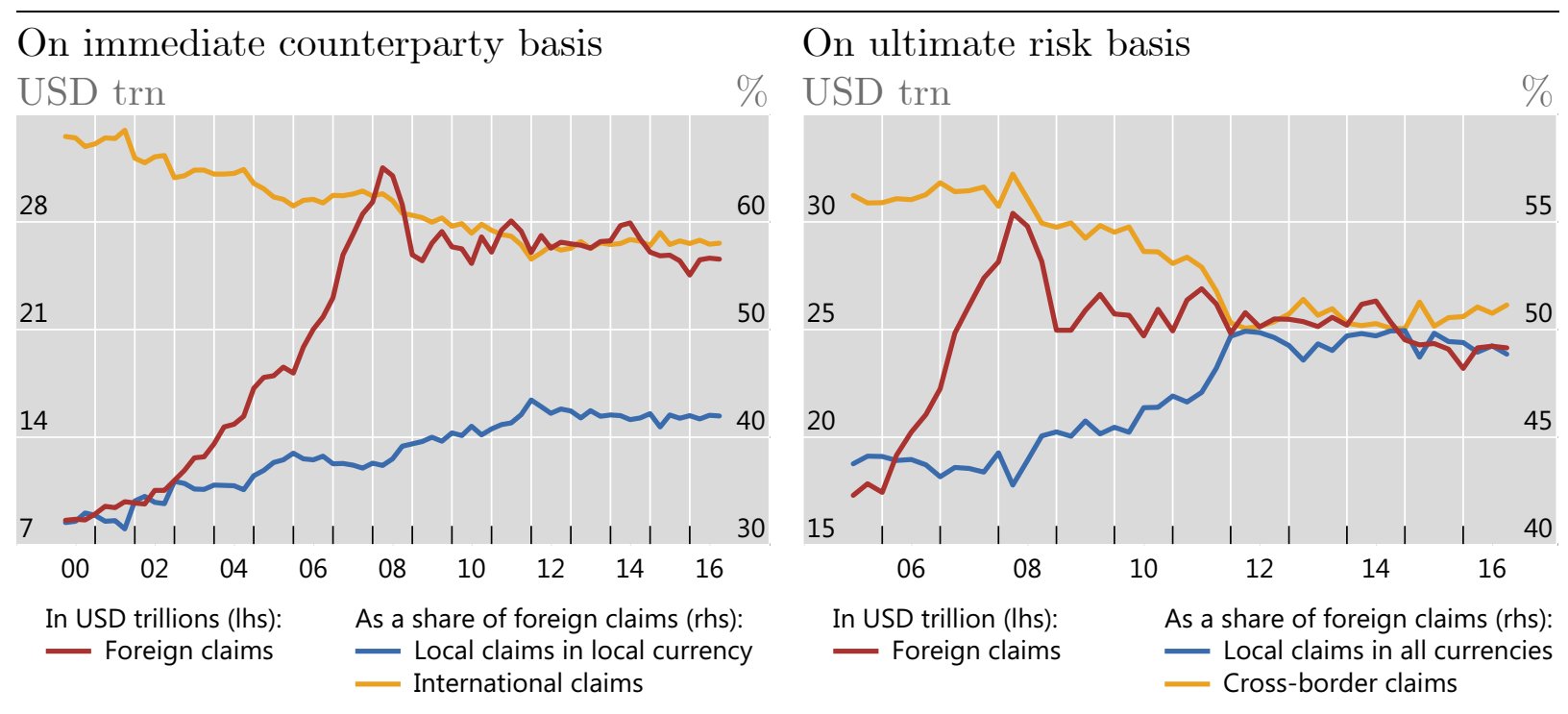

Notes: The figure is based on data of internationally active banks headquartered in countries that report to the BIS consolidated banking statistics (CBS). More detailed information about the BIS CBS is available at: https://www.bis.org/statistics/consstats.htm. 


\section{Table 1. Descriptive statistics}

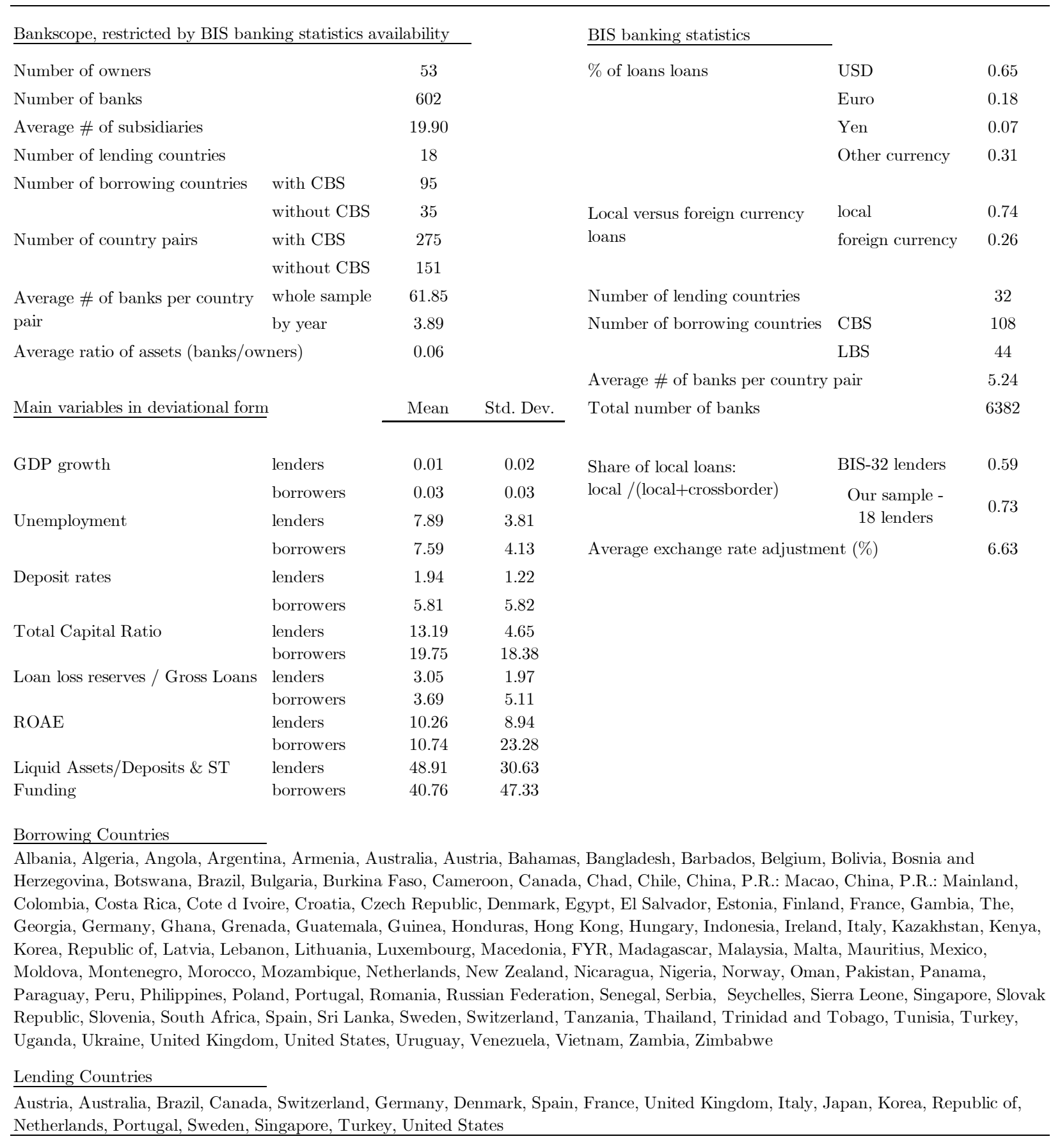

Notes: This table reports descriptive statistics from our dataset and the BIS banking database, and provides a list of the countries that we include. The definitions of the reported statistics are provided in Appendix A. 


\section{Table 2. Subsidiary and host-nation-specific factors}

\begin{tabular}{|c|c|c|c|c|c|c|c|}
\hline \multirow[b]{3}{*}{$\gamma_{1}^{h}$} & \multicolumn{3}{|c|}{ Macroeconomic variables } & \multicolumn{4}{|c|}{ Banks' ratios } \\
\hline & GDP & Unemployment & Deposit rate & Capital Adequacy & Asset Quality & Performance & Liquidity \\
\hline & $\begin{array}{c}0.7437 \\
(0.0160)^{* *}\end{array}$ & $\begin{array}{c}-0.1088 \\
(0.0047)^{* * *}\end{array}$ & $\begin{array}{c}-0.0031 \\
(0.0071)^{* * *}\end{array}$ & $\begin{array}{c}0.0058 \\
(0.0000)^{* * *}\end{array}$ & $\begin{array}{c}0.0063 \\
(0.0963)^{*}\end{array}$ & $\begin{array}{c}0.0010 \\
(0.0001)^{* * *}\end{array}$ & $\begin{array}{c}0.0016 \\
(0.0000)^{* * *}\end{array}$ \\
\hline$\sum_{k=1}^{2} \lambda_{k}$ & $\begin{array}{l}-0.0196 \\
(0.3474)\end{array}$ & $\begin{array}{l}-0.0428 \\
(0.1561)\end{array}$ & $\begin{array}{c}-0.0151 \\
(0.0480)^{* *}\end{array}$ & $\begin{array}{c}0.0417 \\
(0.0017)^{* * *}\end{array}$ & $\begin{array}{c}0.0560 \\
(0.0001)^{* * *}\end{array}$ & $\begin{array}{c}0.0040 \\
(0.3508)\end{array}$ & $\begin{array}{c}0.0452 \\
(0.1575)\end{array}$ \\
\hline Owner's capital adequacy & $\begin{array}{l}-0.0006 \\
(0.5942)\end{array}$ & $\begin{array}{l}-0.0008 \\
(0.5969)\end{array}$ & $\begin{array}{l}-0.0020 \\
(0.3028)\end{array}$ & $\begin{array}{l}-0.0005 \\
(0.8740)\end{array}$ & $\begin{array}{l}-0.0017 \\
(0.2480)\end{array}$ & $\begin{array}{l}-0.0010 \\
(0.3938)\end{array}$ & $\begin{array}{l}-0.0019 \\
(0.2374)\end{array}$ \\
\hline Owner's asset quality & $\begin{array}{c}0.0026 \\
(0.5999)\end{array}$ & $\begin{array}{c}0.0021 \\
(0.7015)\end{array}$ & $\begin{array}{c}0.0008 \\
(0.8672)\end{array}$ & $\begin{array}{l}-0.0020 \\
(0.5840)\end{array}$ & $\begin{array}{c}0.0017 \\
(0.5826)\end{array}$ & $\begin{array}{c}0.0019 \\
(0.7482)\end{array}$ & $\begin{array}{c}0.0030 \\
(0.5900)\end{array}$ \\
\hline Owner's performance & $\begin{array}{l}-0.0004 \\
(0.4923)\end{array}$ & $\begin{array}{l}-0.0003 \\
(0.6432)\end{array}$ & $\begin{array}{c}0.0005 \\
(0.5599)\end{array}$ & $\begin{array}{c}0.0002 \\
(0.7277)\end{array}$ & $\begin{array}{l}-0.0003 \\
(0.7185)\end{array}$ & $\begin{array}{l}-0.0004 \\
(0.4448)\end{array}$ & $\begin{array}{c}0.0000 \\
(0.9410)\end{array}$ \\
\hline Owner's liquidity & $\begin{array}{c}0.0005 \\
(0.1108)\end{array}$ & $\begin{array}{c}0.0007 \\
(0.0557)^{*}\end{array}$ & $\begin{array}{c}0.0005 \\
(0.2866)\end{array}$ & $\begin{array}{c}0.0006 \\
(0.2441)\end{array}$ & $\begin{array}{c}0.0006 \\
(0.1485)\end{array}$ & $\begin{array}{c}0.0005 \\
(0.1288)\end{array}$ & $\begin{array}{c}0.0006 \\
(0.0940)^{*}\end{array}$ \\
\hline Number of observations & 2,881 & 2,588 & 1,886 & 1,668 & 2,375 & 3,016 & 2,993 \\
\hline Hansen test & 0.7853 & 0.7769 & 0.8908 & 0.9137 & 0.9912 & 0.8717 & 0.7887 \\
\hline AR2 test & 0.5621 & 0.6295 & 0.8370 & 0.7655 & 0.8960 & 0.4981 & 0.4246 \\
\hline
\end{tabular}

Notes: This table reports the results obtained from the estimation of equation (7). Capital adequacy, asset quality, performance and liquidity of both owners and banks are captured by the total capital ratio, loan loss reserves to gross loans ratio, return on average equity and the liquid assets to total deposits and short term funding ratio, respectively. The number is parentheses, and the statistic reported for the Hansen test are the p-values. AR2 test row reports zvalues. *, **, *** significant at $10 \%, 5 \%, 1 \%$, respectively. 
Table 3. Owner IAB and lender-nation-specific factors

\begin{tabular}{|c|c|c|c|c|c|c|c|}
\hline \multirow[b]{3}{*}{$\gamma_{1}^{l}$} & \multicolumn{3}{|c|}{ Macroeconomic variables } & \multicolumn{4}{|c|}{ Owner s ratios } \\
\hline & GDP & Unemployment & Deposit rate & Capital Adequacy & Asset Quality & Performance & Liquidity \\
\hline & $\begin{array}{c}1.3230 \\
(0.0244)^{* *}\end{array}$ & $\begin{array}{l}-0.0378 \\
(0.6408)\end{array}$ & $\begin{array}{c}-0.0386 \\
(0.2521)\end{array}$ & $\begin{array}{c}0.0005 \\
(0.1636)\end{array}$ & $\begin{array}{c}0.0010 \\
(0.5866)\end{array}$ & $\begin{array}{c}0.0022 \\
(0.0889)^{*}\end{array}$ & $\begin{array}{c}-0.0002 \\
(0.6130)\end{array}$ \\
\hline$\sum_{k=1}^{2} \lambda_{k}$ & $\begin{array}{c}0.0347 \\
(0.3983)\end{array}$ & $\begin{array}{c}0.0369 \\
(0.3732)\end{array}$ & $\begin{array}{l}-0.0850 \\
(0.6144)\end{array}$ & $\begin{array}{c}0.0517 \\
(0.1884)\end{array}$ & $\begin{array}{c}0.0482 \\
(0.1870)\end{array}$ & $\begin{array}{c}0.0429 \\
(0.1814)\end{array}$ & $\begin{array}{c}0.0531 \\
(0.1625)\end{array}$ \\
\hline Bank's capital adequacy & $\begin{array}{c}0.0005 \\
(0.7561)\end{array}$ & $\begin{array}{c}0.0005 \\
(0.7566)\end{array}$ & $\begin{array}{l}-0.0009 \\
(0.6404)\end{array}$ & $\begin{array}{c}0.0022 \\
(0.3039)\end{array}$ & $\begin{array}{c}0.0021 \\
(0.3202)\end{array}$ & $\begin{array}{c}0.0021 \\
(0.3145)\end{array}$ & $\begin{array}{c}0.0022 \\
(0.2983)\end{array}$ \\
\hline Bank's asset quality & $\begin{array}{c}0.0063 \\
(0.1619)\end{array}$ & $\begin{array}{c}0.0062 \\
(0.1720)\end{array}$ & $\begin{array}{l}-0.0060 \\
(0.3702)\end{array}$ & $\begin{array}{c}0.0051 \\
(0.3877)\end{array}$ & $\begin{array}{c}0.0054 \\
(0.3534)\end{array}$ & $\begin{array}{c}0.0050 \\
(0.3701)\end{array}$ & $\begin{array}{c}0.0050 \\
(0.3849)\end{array}$ \\
\hline Bank's performance & $\begin{array}{c}0.0009 \\
(0.0000)^{* * *}\end{array}$ & $\begin{array}{c}0.0009 \\
(0.0000)^{* * *}\end{array}$ & $\begin{array}{c}0.0013 \\
(0.1382)\end{array}$ & $\begin{array}{c}0.0102 \\
(0.2752)\end{array}$ & $\begin{array}{c}0.0103 \\
(0.2664)\end{array}$ & $\begin{array}{c}0.0097 \\
(0.2955)\end{array}$ & $\begin{array}{c}0.0099 \\
(0.2862)\end{array}$ \\
\hline Bank's liquidity & $\begin{array}{c}0.0001 \\
(0.7730)\end{array}$ & $\begin{array}{c}0.0001 \\
(0.8133)\end{array}$ & $\begin{array}{l}-0.0001 \\
(0.7920)\end{array}$ & $\begin{array}{l}-0.0001 \\
(0.8047)\end{array}$ & $\begin{array}{l}-0.0001 \\
(0.8274)\end{array}$ & $\begin{array}{c}0.0000 \\
(0.8573)\end{array}$ & $\begin{array}{c}0.0000 \\
(0.8568)\end{array}$ \\
\hline Number of observations & 1535 & 1535 & 458 & 1291 & 1304 & 1319 & 1328 \\
\hline Hansen test & 0.9867 & 0.9738 & 1.0000 & 0.9557 & 0.9534 & 0.9310 & 0.9545 \\
\hline AR2 test & 0.3569 & 0.4078 & 0.5836 & 0.3765 & 0.3562 & 0.3969 & 0.3737 \\
\hline
\end{tabular}

Notes: This table reports the results obtained from the estimation of equation (9). Capital adequacy, asset quality, performance and liquidity of both owners and banks are captured by the total capital ratio, loan loss reserves to gross loans ratio, return on average equity and the liquid assets to total deposits and short term funding ratio, respectively. The number is parentheses, and the statistic reported for the Hansen test are the p-values. AR2 test row reports zvalues. *, **, *** significant at $10 \%, 5 \%, 1 \%$, respectively. 
Table 4. Other macroeconomic factors

\begin{tabular}{|c|c|c|}
\hline & Deviations across host nations & Deviations across lending nations \\
\hline \multirow[t]{2}{*}{ GDP } & 0.7437 & 1.3230 \\
\hline & $(0.0160)^{* *}$ & $(0.0244)^{* *}$ \\
\hline \multirow[t]{2}{*}{ Unemployment } & -0.1088 & -0.0378 \\
\hline & $(0.0047)^{* * *}$ & $(0.6408)$ \\
\hline \multirow[t]{2}{*}{ Exchange rate } & 0.2413 & -0.2022 \\
\hline & $(0.0042)^{* * *}$ & $(0.3148)$ \\
\hline \multirow[t]{2}{*}{ Deposit rate } & -0.0031 & -0.0386 \\
\hline & $(0.0071)^{* * *}$ & $(0.2521)$ \\
\hline \multirow[t]{2}{*}{ Lending rate } & -0.1377 & -0.1025 \\
\hline & $(0.0004)^{* * *}$ & $(0.1302)$ \\
\hline \multirow[t]{2}{*}{ Money market rate } & -0.0050 & 0.0005 \\
\hline & $(0.0612)^{*}$ & $(0.5769)$ \\
\hline \multirow[t]{2}{*}{ T-Bill rate } & -0.0018 & 0.0003 \\
\hline & $(0.0144)^{* *}$ & $(0.6440)$ \\
\hline \multirow[t]{2}{*}{ Central bank policy rate } & -0.0152 & 0.0121 \\
\hline & $(0.5053)$ & $(0.6044)$ \\
\hline \multirow[t]{2}{*}{ Equity } & 0.1391 & 0.0308 \\
\hline & $(0.0790)^{*}$ & $(0.7583)$ \\
\hline
\end{tabular}

Notes: This table reports the coefficients of the macroeconomic variables in equations (7) and (9) in column 1 and 2, respectively. The number is parentheses are the p-values. ${ }^{*}, * *, * *$ significant at $10 \%, 5 \%, 1 \%$, respectively. 


\section{Table 5. Other financial ratios}

\begin{tabular}{|c|c|c|c|c|c|c|c|c|c|}
\hline \multirow[b]{3}{*}{$\begin{array}{l}\text { Total Capital } \\
\text { Ratio }\end{array}$} & \multicolumn{4}{|c|}{ Capital Adequacy } & & \multicolumn{4}{|c|}{ Performance } \\
\hline & \multirow{2}{*}{$\begin{array}{c}\begin{array}{c}\text { Deviations } \\
\text { across host } \\
\text { nations }\end{array} \\
0.0058\end{array}$} & \multicolumn{3}{|c|}{$\begin{array}{c}\text { Deviations } \\
\text { across lending } \\
\text { nations }\end{array}$} & \multirow[b]{2}{*}{$\begin{array}{l}\text { Net Interest } \\
\text { Margin }\end{array}$} & \multirow{2}{*}{$\begin{array}{c}\begin{array}{c}\text { Deviations } \\
\text { across host } \\
\text { nations }\end{array} \\
-0.0058\end{array}$} & \multicolumn{3}{|c|}{$\begin{array}{c}\text { Deviations } \\
\text { across lending } \\
\text { nations } \\
\end{array}$} \\
\hline & & $(0.0000)^{* * *}$ & 0.0005 & $(0.2507)$ & & & $(0.1584)$ & 0.0266 & $(0.1325)$ \\
\hline Tier 1 Ratio & 0.0076 & $(0.0000)^{* * *}$ & 0.0032 & $(0.6237)$ & $\begin{array}{l}\text { Net Int Rev / } \\
\text { Avg Assets }\end{array}$ & -0.0118 & $(0.0179)^{* *}$ & 0.0271 & $(0.1753)$ \\
\hline $\begin{array}{l}\text { Equity / Tot } \\
\text { Assets }\end{array}$ & 0.0051 & $(0.0461)^{* *}$ & 0.0179 & $(0.0259)^{* *}$ & $\begin{array}{l}\text { Oth Op Inc / } \\
\text { Avg Assets }\end{array}$ & 0.0065 & $(0.0303)^{* *}$ & 0.0102 & $(0.3732)$ \\
\hline $\begin{array}{l}\text { Equity / Net } \\
\text { Loans }\end{array}$ & 0.0015 & $(0.0000)^{* * *}$ & 0.0034 & $(0.0015)^{* * *}$ & $\begin{array}{l}\text { Non Int Exp / } \\
\text { Avg Assets }\end{array}$ & -0.0036 & $(0.3367)$ & 0.0100 & $(0.3018)$ \\
\hline $\begin{array}{l}\text { Equity / Cust } \\
\& \text { ST Funding }\end{array}$ & 0.0018 & $(0.0015)^{* * *}$ & 0.0072 & $(0.0645)^{*}$ & $\begin{array}{l}\text { Pre-Tax Op Inc } \\
\text { / Avg Assets }\end{array}$ & 0.0073 & $(0.2235)$ & 0.0057 & $(0.7218)$ \\
\hline $\begin{array}{l}\text { Equity / } \\
\text { Liabilities }\end{array}$ & 0.0011 & $(0.0855)^{*}$ & 0.0160 & $(0.0186)^{* *}$ & $\begin{array}{l}\text { Non Op Items \& } \\
\text { Taxes / Avg Ast }\end{array}$ & -0.0038 & $(0.5286)$ & 0.0404 & $(0.2098)$ \\
\hline $\begin{array}{l}\text { Cap Funds / } \\
\text { Tot Assets }\end{array}$ & 0.0067 & $(0.0024)^{* * *}$ & 0.0157 & $(0.0320)^{* *}$ & $\begin{array}{l}\text { Return On Avg } \\
\text { Assets (ROAA) }\end{array}$ & 0.0061 & $(0.3078)$ & 0.0395 & $(0.0583)^{*}$ \\
\hline $\begin{array}{l}\text { Cap Funds / } \\
\text { Net Loans }\end{array}$ & 0.0012 & $(0.0001)^{* * *}$ & 0.0028 & $(0.0017)^{* * *}$ & $\begin{array}{l}\text { Return On Avg } \\
\text { Equity (ROAE) }\end{array}$ & 0.0010 & $(0.0001)^{* * *}$ & 0.0022 & $(0.0889)^{*}$ \\
\hline $\begin{array}{l}\text { Cap Funds / } \\
\text { Dep \& ST } \\
\text { Funding }\end{array}$ & 0.0014 & $(0.2378)$ & 0.0061 & $(0.0446)^{* *}$ & $\begin{array}{l}\text { Dividend Pay- } \\
\text { Out }\end{array}$ & 0.0000 & $(0.8488)$ & -0.0003 & $(0.0281)^{* *}$ \\
\hline $\begin{array}{l}\text { Cap Funds / } \\
\text { Liabilities }\end{array}$ & 0.0022 & $(0.1088)$ & 0.0140 & $(0.0196)^{* *}$ & $\begin{array}{l}\text { Inc Net Of Dist } \\
\text { / Avg Equity }\end{array}$ & 0.0012 & $(0.0010)^{* * *}$ & 0.0026 & $(0.0847)^{*}$ \\
\hline \multirow[t]{4}{*}{$\begin{array}{l}\text { Subord Debt / } \\
\text { Cap Funds }\end{array}$} & -0.0010 & $(0.4006)$ & -0.0011 & $(0.4949)$ & $\begin{array}{l}\text { Non Op Items / } \\
\text { Net Income }\end{array}$ & -0.0001 & $(0.4953)$ & 0.0001 & $(0.1618)$ \\
\hline & & & & & $\begin{array}{l}\text { Cost To Income } \\
\text { Ratio }\end{array}$ & 0.0003 & $(0.4456)$ & 0.0005 & $(0.3623)$ \\
\hline & \multicolumn{4}{|c|}{ Asset Quality } & & \multicolumn{4}{|c|}{ Liquidity } \\
\hline & $\begin{array}{r}\text { Deviations } \\
\text { across host } \\
\end{array}$ & & $\begin{array}{l}\text { Deviations } \\
\text { across lending }\end{array}$ & & & $\begin{array}{r}\text { Deviations } \\
\text { across host }\end{array}$ & & $\begin{array}{c}\text { Deviations } \\
\text { across lending }\end{array}$ & \\
\hline $\begin{array}{l}\text { Loan Loss Res } \\
\text { / Gross Loans }\end{array}$ & -0.0063 & $(0.0963)^{*}$ & 0.0009 & $(0.6353)$ & Interbank Ratio & 0.0001 & $(0.1088)$ & 0.0001 & $(0.4562)$ \\
\hline $\begin{array}{l}\text { Loan Loss Prov } \\
\text { / Net Int Rev }\end{array}$ & -0.0006 & $(0.0299)^{* *}$ & -0.0006 & $(0.0952)^{*}$ & $\begin{array}{l}\text { Net Loans / Tot } \\
\text { Assets }\end{array}$ & -0.0056 & $(0.0000)^{* * *}$ & -0.0005 & $(0.7101)$ \\
\hline $\begin{array}{l}\text { Loan Loss Res } \\
\text { / Impair. Loans }\end{array}$ & 0.0004 & $(0.0000)^{* * *}$ & -0.0002 & $(0.0702)^{*}$ & $\begin{array}{l}\text { Net Loans / } \\
\text { Dep \& ST } \\
\text { Funding }\end{array}$ & -0.0014 & $(0.0008)^{* * *}$ & -0.0005 & $(0.3922)$ \\
\hline $\begin{array}{l}\text { Impaired Loans } \\
\text { / Gross Loans }\end{array}$ & -0.0099 & $(0.0000)^{* * *}$ & -0.0060 & $(0.2468)$ & $\begin{array}{l}\text { Net Loans / Tot } \\
\text { Dep \& Bor }\end{array}$ & -0.0028 & $(0.0000)^{* * *}$ & 0.0010 & $(0.3539)$ \\
\hline $\begin{array}{l}\text { NCO / Average } \\
\text { Gross Loans }\end{array}$ & -0.0044 & $(0.1035)$ & -0.0007 & $(0.9558)$ & $\begin{array}{l}\text { Liquid Assets / } \\
\text { Dep \& ST } \\
\text { Funding }\end{array}$ & 0.0016 & $(0.0000)^{* * *}$ & -0.0003 & $(0.5057)$ \\
\hline $\begin{array}{l}\text { NCO / Net Inc } \\
\text { Bef Ln Lss } \\
\text { Prov. }\end{array}$ & 0.0000 & $(0.7367)$ & -0.0003 & $(0.0830)^{*}$ & $\begin{array}{l}\text { Liquid Assets / } \\
\text { Total Debt and } \\
\text { Borr. }\end{array}$ & 0.0030 & $(0.0000)^{* * *}$ & -0.0004 & $(0.7661)$ \\
\hline $\begin{array}{l}\text { Impaired Loans } \\
\text { / Equity }\end{array}$ & -0.0008 & $(0.0000)^{* * *}$ & -0.0007 & $(0.2430)$ & & & & & \\
\hline $\begin{array}{l}\text { Unres. Impair. } \\
\text { Loans / Equity }\end{array}$ & -0.0010 & $(0.0001)^{* * *}$ & -0.0022 & $(0.0504)^{*}$ & & & & & \\
\hline
\end{tabular}

Notes: To obtain the estimation results in this table we replace our baseline indicators of bank and owner capital adequacy, performance, asset quality and liquidity in equations (7) and (9) with other measures. For each of the four blocks, the first and last two columns report the main independent variable's coefficient in equation (7) and (9), respectively. The number is parentheses are the p-values. ${ }^{*}, * *, * * *$ significant at $10 \%, 5 \%, 1 \%$, respectively. 
Table 6. Pull-push interaction, Subsidiary and host-nation-specific factors

\begin{tabular}{|c|c|c|c|c|c|c|c|c|}
\hline & & GDP & Unemployment & $\begin{array}{c}\text { Deposit } \\
\text { rate }\end{array}$ & $\begin{array}{c}\text { Capital } \\
\text { Adequacy }\end{array}$ & $\begin{array}{c}\text { Asset } \\
\text { Quality }\end{array}$ & Performance & Liquidity \\
\hline Baseline & & $\begin{array}{c}0.7437 \\
(0.0160)^{* *}\end{array}$ & $\begin{array}{c}-0.1088 \\
(0.0047)^{* * *}\end{array}$ & $\begin{array}{c}-0.0031 \\
(0.0071)^{* * *}\end{array}$ & $\begin{array}{c}0.0058 \\
(0.0000)^{* * * *}\end{array}$ & $\begin{array}{c}0.0063 \\
(0.0963)^{*}\end{array}$ & $\begin{array}{c}0.0010 \\
(0.0001)^{* * *}\end{array}$ & $\begin{array}{c}0.0016 \\
(0.0000)^{* * *}\end{array}$ \\
\hline \multicolumn{9}{|c|}{ With pull-push interaction } \\
\hline \multirow[t]{2}{*}{ GDP } & $\gamma_{1}$ & $\begin{array}{c}0.9130 \\
(0.0177)^{* *}\end{array}$ & $\begin{array}{c}-0.1013 \\
(0.0188)^{* *}\end{array}$ & $\begin{array}{c}-0.0042 \\
(0.0009)^{* * *}\end{array}$ & $\begin{array}{c}0.0064 \\
(0.0000)^{* * *}\end{array}$ & $\begin{array}{c}0.0084 \\
(0.0443)^{* *}\end{array}$ & $\begin{array}{c}0.0012 \\
(0.0001)^{* * *}\end{array}$ & $\begin{array}{c}0.0015 \\
(0.0000)^{* * * *}\end{array}$ \\
\hline & $\varphi_{1}$ & $\begin{array}{c}-11.9983 \\
(0.3736)\end{array}$ & $\begin{array}{l}-4.2982 \\
(0.2719)\end{array}$ & $\begin{array}{c}0.0277 \\
(0.5868)\end{array}$ & $\begin{array}{c}0.0672 \\
(0.5095)\end{array}$ & $\begin{array}{l}-0.0045 \\
(0.9846)\end{array}$ & $\begin{array}{l}-0.0603 \\
(0.0453)\end{array}$ & $\begin{array}{l}-0.0156 \\
(0.6245)\end{array}$ \\
\hline \multirow[t]{2}{*}{ Unemployment } & $\gamma_{1}$ & $\begin{array}{c}0.8509 \\
(0.0277)^{* *}\end{array}$ & $\begin{array}{c}-0.1058 \\
(0.0171)^{* *}\end{array}$ & $\begin{array}{c}-0.0042 \\
(0.0009)^{* * *}\end{array}$ & $\begin{array}{c}0.0066 \\
(0.0000)^{* * *}\end{array}$ & $\begin{array}{c}0.0094 \\
(0.0237)^{* *}\end{array}$ & $\begin{array}{c}0.0010 \\
(0.0102)^{* *}\end{array}$ & $\begin{array}{c}0.0015 \\
(0.0000)^{* * *}\end{array}$ \\
\hline & $\varphi_{1}$ & $\begin{array}{c}0.7194 \\
(0.7682)\end{array}$ & $\begin{array}{l}-0.0653 \\
(0.8244)\end{array}$ & $\begin{array}{l}-0.0093 \\
(0.6388)\end{array}$ & $\begin{array}{c}0.0021 \\
(0.8357)\end{array}$ & $\begin{array}{c}-0.0530 \\
(0.0137)^{* *}\end{array}$ & $\begin{array}{l}-0.0011 \\
(0.5538)\end{array}$ & $\begin{array}{c}0.0058 \\
(0.0070)^{* * *}\end{array}$ \\
\hline \multirow[t]{3}{*}{ Deposit Rate } & $\gamma_{1}$ & $\begin{array}{c}0.8581 \\
(0.4415)\end{array}$ & $\begin{array}{l}-0.0739 \\
(0.4367)\end{array}$ & $\begin{array}{l}-0.0744 \\
(0.2184)\end{array}$ & $\begin{array}{c}0.0112 \\
(0.0009)^{* * *}\end{array}$ & $\begin{array}{c}0.0039 \\
(0.6652)\end{array}$ & $\begin{array}{l}-0.0011 \\
(0.1283)\end{array}$ & $\begin{array}{c}0.0017 \\
(0.0004)^{* * *}\end{array}$ \\
\hline & $\varphi_{1}$ & $\begin{array}{c}-5.3061 \\
(0.0373)^{* *}\end{array}$ & $\begin{array}{c}0.0444 \\
(0.9172)\end{array}$ & $\begin{array}{l}-0.0526 \\
(0.2338)\end{array}$ & $\begin{array}{c}0.0045 \\
(0.6485)\end{array}$ & $\begin{array}{c}0.0156 \\
(0.6985)\end{array}$ & $\begin{array}{l}-0.0004 \\
(0.9168)\end{array}$ & $\begin{array}{l}-0.0009 \\
(0.7390)\end{array}$ \\
\hline & $\gamma_{1}$ & $\begin{array}{c}0.8645 \\
(0.0102)^{* *}\end{array}$ & $\begin{array}{c}-0.1028 \\
(0.0218)^{* *}\end{array}$ & $\begin{array}{c}-0.0039 \\
(0.0039)^{* * *}\end{array}$ & $\begin{array}{c}0.0063 \\
(0.0000)^{* * *}\end{array}$ & $\begin{array}{c}0.0063 \\
(0.0977)^{*}\end{array}$ & $\begin{array}{c}0.0010 \\
(0.0001)^{* * *}\end{array}$ & $\begin{array}{c}0.0016 \\
(0.0000)^{* * *}\end{array}$ \\
\hline Capital Adequacy & $\varphi_{1}$ & $\begin{array}{l}-0.0081 \\
(0.9439)\end{array}$ & $\begin{array}{c}0.0098 \\
(0.4283)\end{array}$ & $\begin{array}{l}-0.0001 \\
(0.9007)\end{array}$ & $\begin{array}{c}-0.0001 \\
(0.0648)^{*}\end{array}$ & $\begin{array}{l}-0.0002 \\
(0.8045)\end{array}$ & $\begin{array}{c}0.0002 \\
(0.0208)^{* *}\end{array}$ & $\begin{array}{c}0.0002 \\
(0.0818)^{*}\end{array}$ \\
\hline \multirow[t]{3}{*}{ Asset Quality } & $\gamma_{1}$ & $\begin{array}{c}0.8779 \\
(0.0131)^{* *}\end{array}$ & $\begin{array}{c}-0.1086 \\
(0.0158)^{* *}\end{array}$ & $\begin{array}{c}-0.0040 \\
(0.0048)^{* * *}\end{array}$ & $\begin{array}{c}0.0062 \\
(0.0000)^{* * *}\end{array}$ & $\begin{array}{c}0.0068 \\
(0.0652)^{*}\end{array}$ & $\begin{array}{c}0.0008 \\
(0.0055)^{* * *}\end{array}$ & $\begin{array}{c}0.0015 \\
(0.0000)^{* * *}\end{array}$ \\
\hline & $\varphi_{1}$ & $\begin{array}{c}0.2671 \\
(0.2128)\end{array}$ & $\begin{array}{l}-0.0288 \\
(0.4382)\end{array}$ & $\begin{array}{c}0.0005 \\
(0.7441)\end{array}$ & $\begin{array}{c}0.0003 \\
(0.7066)\end{array}$ & $\begin{array}{l}-0.0001 \\
(0.7342)\end{array}$ & $\begin{array}{l}-0.0004 \\
(0.1794)\end{array}$ & $\begin{array}{l}0.0004 \\
(0.259)\end{array}$ \\
\hline & $\gamma_{1}$ & $\begin{array}{c}0.8892 \\
(0.0079)^{* * *}\end{array}$ & $\begin{array}{c}-0.1076 \\
(0.0129)^{* *}\end{array}$ & $\begin{array}{c}-0.0040 \\
(0.0343)^{* *}\end{array}$ & $\begin{array}{c}0.0063 \\
(0.0000)^{* * *}\end{array}$ & $\begin{array}{c}0.0052 \\
(0.0455)^{* *}\end{array}$ & $\begin{array}{c}0.0012 \\
(0.0006)^{* * *}\end{array}$ & $\begin{array}{c}0.0015 \\
(0.0000)^{* * *}\end{array}$ \\
\hline \multirow{2}{*}{ Performance } & $\varphi_{1}$ & $\begin{array}{c}0.0177 \\
(0.7451)\end{array}$ & $\begin{array}{c}0.0004 \\
(0.9527)\end{array}$ & $\begin{array}{c}0.0001 \\
(0.8642)\end{array}$ & $\begin{array}{c}0.0002 \\
(0.1934)\end{array}$ & $\begin{array}{c}0.0013 \\
(0.0003)^{* * *}\end{array}$ & $\begin{array}{c}0.0000 \\
(0.0076)^{* * *}\end{array}$ & $\begin{array}{l}-0.0001 \\
(0.1530)\end{array}$ \\
\hline & $\gamma_{1}$ & $\begin{array}{c}0.8750 \\
(0.0102)^{* *}\end{array}$ & $\begin{array}{c}-0.1042 \\
(0.0152)^{* *}\end{array}$ & $\begin{array}{c}-0.0041 \\
(0.0068)^{* * *}\end{array}$ & $\begin{array}{c}0.0064 \\
(0.0000)^{* * *}\end{array}$ & $\begin{array}{c}0.0065 \\
(0.0711)^{*}\end{array}$ & $\begin{array}{c}0.0009 \\
(0.0017)^{* * *}\end{array}$ & $\begin{array}{c}0.0015 \\
(0.0001)^{* * *}\end{array}$ \\
\hline Liquidity & $\varphi_{1}$ & $\begin{array}{l}-0.0173 \\
(0.2714)\end{array}$ & $\begin{array}{l}-0.0019 \\
(0.3340)\end{array}$ & $\begin{array}{c}0.0001 \\
(0.5128)\end{array}$ & $\begin{array}{c}0.0000 \\
(0.5673)\end{array}$ & $\begin{array}{c}0.0000 \\
(0.8390)\end{array}$ & $\begin{array}{c}0.0000 \\
(0.4633)\end{array}$ & $\begin{array}{c}0.0000 \\
(0.1886)\end{array}$ \\
\hline
\end{tabular}

Notes: To obtain the estimation results in this table we expand equation (7) by including an interactive term derived by the multiplication of owner/lender-nation specific factors with subsidiary/host-nation specific factors. This expanded model is given by equation (10) in Section 4.3. The subsidiary/host-nation specific variables that we associate with pull effects are listed in the columns and for each of these variables we include an interactive term derived from multiplying them by the owner/lender-nation specific factors listed in the rows of the table. $\gamma_{1}$ as before represents the coefficient of the pull factor and $\varphi_{1}$ is the coefficient of the interactive term. Capital adequacy, asset quality, performance and liquidity of both owners and banks are captured by the total capital ratio, loan loss reserves to gross loans ratio, return on average equity and the liquid assets to total deposits and short term funding ratio, respectively. $*, * *, * * *$ significant at $10 \%, 5 \%, 1 \%$, respectively. 
Table 7. Pull-push interaction, Owner and lender-nation-specific factors

\begin{tabular}{|c|c|c|c|c|c|c|c|c|}
\hline & & GDP & Unemployment & $\begin{array}{c}\text { Deposit } \\
\text { rate }\end{array}$ & $\begin{array}{c}\text { Capital } \\
\text { Adequacy }\end{array}$ & $\begin{array}{c}\text { Asset } \\
\text { Quality }\end{array}$ & Performance & Liquidity \\
\hline \multirow{2}{*}{\multicolumn{2}{|c|}{ Baseline }} & 1.3230 & -0.0378 & -0.0386 & 0.0005 & 0.0010 & 0.0022 & -0.0002 \\
\hline & & $(0.0244)^{* *}$ & $(0.6408)$ & $(0.2521)$ & $(0.1636)$ & $(0.5866)$ & $(0.0889)^{*}$ & $(0.6130)$ \\
\hline \multicolumn{9}{|c|}{ With pull-push interaction } \\
\hline \multirow{4}{*}{ GDP } & $\gamma_{1}$ & 1.3102 & -0.0357 & -0.1184 & 0.0007 & 0.0019 & 0.0022 & -0.0003 \\
\hline & & $(0.0463)^{* *}$ & $(0.6686)$ & $(0.0585)^{*}$ & $(0.4836)$ & $(0.6477)$ & $(0.1009)$ & $(0.5114)$ \\
\hline & $\varphi_{1}$ & 1.7909 & -4.5226 & 1.2826 & 0.0940 & 0.0377 & -0.0270 & 0.0049 \\
\hline & & $(0.8749)$ & $(0.3009)$ & $(0.7596)$ & $(0.2798)$ & $(0.8837)$ & $(0.3666)$ & $(0.8516)$ \\
\hline \multirow{5}{*}{ Unemployment } & $\gamma_{1}$ & 1.2773 & -0.0487 & -0.1195 & 0.0007 & 0.0017 & 0.0022 & -0.0003 \\
\hline & & $(0.0333)^{* *}$ & $(0.5649)$ & $(0.0710)^{*}$ & $(0.4734)$ & $(0.6674)$ & $(0.1066)$ & $(0.4787)$ \\
\hline & $\varphi_{1}$ & -4.9324 & 0.9430 & -0.5069 & -0.0017 & 0.0389 & 0.0015 & -0.0018 \\
\hline & & $(0.0907)^{*}$ & $(0.0287)^{* *}$ & $(0.5787)$ & $(0.8883)$ & $(0.0436)^{* *}$ & $(0.4898)$ & $(0.5172)$ \\
\hline & $\gamma_{1}$ & 3.3461 & -0.0286 & -0.1147 & 0.0287 & 0.0024 & 0.0113 & -0.0005 \\
\hline \multirow[t]{4}{*}{ Deposit Rate } & & $(0.0093)^{* * *}$ & $(0.8915)$ & $(0.0769)^{*}$ & $(0.4963)$ & $(0.9271)$ & $(0.0978)^{*}$ & $(0.3819)$ \\
\hline & $\varphi_{1}$ & -1.7067 & 0.1743 & 0.0573 & 0.0094 & -0.0093 & -0.0037 & -0.0035 \\
\hline & & $(0.5708)$ & $(0.6864)$ & $(0.6519)$ & $(0.4648)$ & $(0.7391)$ & $(0.5891)$ & $(0.2233)$ \\
\hline & $\gamma_{1}$ & 0.7006 & -0.0827 & -0.0945 & -0.0001 & 0.0027 & 0.0024 & -0.0003 \\
\hline \multirow[t]{4}{*}{ Capital Adequacy } & & $(0.2725)$ & $(0.3371)$ & $(0.5681)$ & $(0.9390)$ & $(0.2333)$ & $(0.0610)^{*}$ & $(0.4752)$ \\
\hline & $\varphi_{1}$ & 0.0105 & -0.0155 & -0.0347 & 0.0000 & -0.0004 & 0.0000 & 0.0000 \\
\hline & & $(0.8752)$ & $(0.1787)$ & $(0.6815)$ & $(0.4017)$ & $(0.5761)$ & $(0.9150)$ & $(0.6154)$ \\
\hline & $\gamma_{1}$ & 0.6765 & -0.0846 & -0.0621 & 0.0006 & 0.0014 & 0.0021 & -0.0003 \\
\hline \multirow[t]{4}{*}{ Asset Quality } & & $(0.2997)$ & $(0.3198)$ & $(0.6071)$ & $(0.2538)$ & $(0.7306)$ & $(0.1167)$ & $(0.4670)$ \\
\hline & $\varphi_{1}$ & 0.2633 & -0.0389 & 0.0538 & -0.0006 & 0.0000 & -0.0002 & 0.0005 \\
\hline & & $(0.3211)$ & $(0.2222)$ & $(0.5732)$ & $(0.5302)$ & $(0.8766)$ & $(0.5074)$ & $(0.1528)$ \\
\hline & $\gamma_{1}$ & 0.6430 & -0.0856 & -0.0522 & 0.0003 & 0.0016 & 0.0023 & -0.0003 \\
\hline \multirow[t]{4}{*}{ Performance } & & $(0.3097)$ & $(0.3058)$ & $(0.6692)$ & $(0.4816)$ & $(0.4032)$ & $(0.0677)^{*}$ & $(0.5530)$ \\
\hline & $\varphi_{1}$ & -0.0001 & 0.0148 & -0.0606 & 0.0004 & -0.0008 & 0.0000 & 0.0000 \\
\hline & & $(0.9973)$ & $(0.0373)^{* *}$ & $(0.0510)^{*}$ & $(0.1365)$ & $(0.0020)^{* * *}$ & $(0.0158)^{* *}$ & $(0.0314)^{* *}$ \\
\hline & $\gamma_{1}$ & 0.6194 & -0.0849 & -0.2006 & 0.0000 & -0.0001 & 0.0022 & -0.0003 \\
\hline \multirow[t]{3}{*}{ Liquidity } & & $(0.3267)$ & $(0.3152)$ & $(0.0829)^{*}$ & $(0.9301)$ & $(0.9608)$ & $(0.0875)^{*}$ & $(0.4804)$ \\
\hline & $\varphi_{1}$ & -0.0277 & -0.0017 & -0.0076 & 0.0001 & 0.0002 & 0.0000 & 0.0000 \\
\hline & & $(0.1745)$ & $(0.5069)$ & $(0.0871)^{*}$ & $(0.2191)$ & $(0.1427)$ & $(0.7889)$ & $(0.0274)^{* *}$ \\
\hline
\end{tabular}

Notes: To obtain the estimation results in this table we expand equation (9) by including an interactive term derived by the multiplication of owner/lender-nation specific factors with subsidiary/host-nation specific factors. This expanded model is given by equation (11) in Section 4.3. The owner/lender-nation specific variables that we associate with push effects are listed in the columns and for each of these variables we include an interactive term derived from multiplying them by the subsidiary/host-nation specific factors listed in the rows of the table. $\gamma_{1}$ as before represents the coefficient of the push factor and $\varphi_{1}$ is the coefficient of the interactive term. Capital adequacy, asset quality, performance and liquidity of both owners and banks are captured by the total capital ratio, loan loss reserves to gross loans ratio, return on average equity and the liquid assets to total deposits and short term funding ratio, respectively. ${ }^{*},{ }^{* *},{ }^{* * *}$ significant at $10 \%, 5 \%, 1 \%$, respectively. 


\section{Table 8. Sensitivity analysis}

\begin{tabular}{|c|c|c|c|c|c|c|c|c|}
\hline \multirow[b]{3}{*}{ Macroeconomic variable } & \multicolumn{2}{|c|}{ Baseline sample } & \multicolumn{2}{|c|}{44 countries } & \multicolumn{2}{|c|}{$\begin{array}{l}\text { Alternative way of } \\
\text { accounting for M\&A }\end{array}$} & \multicolumn{2}{|c|}{$\begin{array}{l}\text { Unadjusted loan growth } \\
\text { rate }\end{array}$} \\
\hline & eq $(7)$ & eq $(9)$ & eq $(7)$ & eq $(9)$ & eq (7) & eq $(9)$ & eq $(7)$ & eq $(9)$ \\
\hline & & & & & & & & \\
\hline GDP & $\begin{array}{c}0.7437 \\
(0.0160)^{* *}\end{array}$ & $\begin{array}{c}1.3230 \\
(0.0244)^{* *}\end{array}$ & $\begin{array}{c}1.0021 \\
(0.0858)^{*}\end{array}$ & $\begin{array}{c}1.6301 \\
(0.0146)^{* *}\end{array}$ & $\begin{array}{c}0.8998 \\
(0.0841)^{*}\end{array}$ & $\begin{array}{c}2.1435 \\
(0.0045)^{* *}\end{array}$ & $\begin{array}{c}1.0151 \\
(0.0000)^{* * *}\end{array}$ & $\begin{array}{c}0.6533 \\
(0.0996)^{*}\end{array}$ \\
\hline Unemployment & $\begin{array}{c}-0.1088 \\
(0.0047)^{* * *}\end{array}$ & $\begin{array}{l}-0.0378 \\
(0.6408)\end{array}$ & $\begin{array}{l}-0.0970 \\
(0.0510)^{*}\end{array}$ & $\begin{array}{l}-0.0481 \\
(0.6179)\end{array}$ & $\begin{array}{c}-0.1928 \\
(0.0002)^{* * *}\end{array}$ & $\begin{array}{l}-0.2337 \\
(0.0567)^{*}\end{array}$ & $\begin{array}{c}-0.1524 \\
(0.0000)^{* * *}\end{array}$ & $\begin{array}{l}-0.0452 \\
(0.3096)\end{array}$ \\
\hline Deposit rate & $\begin{array}{c}-0.0031 \\
(0.0071)^{* * *}\end{array}$ & $\begin{array}{l}-0.0386 \\
(0.2521)\end{array}$ & $\begin{array}{l}-0.0031 \\
(0.1359)\end{array}$ & $\begin{array}{l}-0.0470 \\
(0.1323)\end{array}$ & $\begin{array}{c}-0.0042 \\
(0.0260)^{* *}\end{array}$ & $\begin{array}{l}-0.0894 \\
(0.1143)\end{array}$ & $\begin{array}{c}-0.0037 \\
(0.0013)^{* * *}\end{array}$ & $\begin{array}{l}-0.0229 \\
(0.4032)\end{array}$ \\
\hline \multicolumn{9}{|l|}{ Ratios } \\
\hline Capital Adequacy & $\begin{array}{c}0.0058 \\
(0.0000)^{* * *}\end{array}$ & $\begin{array}{c}0.0005 \\
(0.1636)\end{array}$ & $\begin{array}{c}0.0054 \\
(0.0001)^{* * *}\end{array}$ & $\begin{array}{c}0.0006 \\
(0.1562)\end{array}$ & $\begin{array}{c}0.0025 \\
(0.0155)^{* *}\end{array}$ & $\begin{array}{c}0.0007 \\
(0.0727)^{*}\end{array}$ & $\begin{array}{c}0.0033 \\
(0.0017)^{* * *}\end{array}$ & $\begin{array}{c}0.0004 \\
(0.4917)\end{array}$ \\
\hline Asset Quality & $\begin{array}{c}0.0063 \\
(0.0963)^{*}\end{array}$ & $\begin{array}{c}0.0010 \\
(0.5866)\end{array}$ & $\begin{array}{c}0.0087 \\
(0.0499)^{* *}\end{array}$ & $\begin{array}{l}-0.0005 \\
(0.7766)\end{array}$ & $\begin{array}{c}0.0102 \\
(0.0093)^{* * *}\end{array}$ & $\begin{array}{c}0.0025 \\
(0.3717)\end{array}$ & $\begin{array}{l}-0.0013 \\
(0.5517)\end{array}$ & $\begin{array}{c}0.0012 \\
(0.5881)\end{array}$ \\
\hline Performance & $\begin{array}{c}0.0010 \\
(0.0001)^{* * *}\end{array}$ & $\begin{array}{c}0.0022 \\
(0.0889)^{*}\end{array}$ & $\begin{array}{c}0.0006 \\
(0.0830)^{*}\end{array}$ & $\begin{array}{c}0.0037 \\
(0.0485)^{* *}\end{array}$ & $\begin{array}{c}0.0010 \\
(0.0045)^{* * *}\end{array}$ & $\begin{array}{c}0.0023 \\
(0.1033)\end{array}$ & $\begin{array}{c}0.0006 \\
(0.0389)^{* *}\end{array}$ & $\begin{array}{c}0.0014 \\
(0.0409)^{* *}\end{array}$ \\
\hline Liquidity & $\begin{array}{c}0.0016 \\
(0.0000)^{* * *}\end{array}$ & $\begin{array}{l}-0.0002 \\
(0.6130)\end{array}$ & $\begin{array}{c}0.0015 \\
(0.0000)^{* * *}\end{array}$ & $\begin{array}{l}-0.0002 \\
(0.7350)\end{array}$ & $\begin{array}{c}0.0014 \\
(0.0001)^{* * *}\end{array}$ & $\begin{array}{l}-0.0006 \\
(0.3456)\end{array}$ & $\begin{array}{c}0.0014 \\
(0.0000)^{* * *}\end{array}$ & $\begin{array}{l}-0.0001 \\
(0.6973)\end{array}$ \\
\hline
\end{tabular}

Notes: This table reports the coefficients of the main independent variables (and their corresponding p-values) in equations (7) and (9) in column 1 and 2, respectively. The p-values are in parentheses. ${ }^{*},{ }^{* *},{ }^{* * *}$ significant at $10 \%$, $5 \%, 1 \%$, respectively. 
Table 9. Sensitivity analysis, continued

\begin{tabular}{|c|c|c|c|c|c|c|c|c|c|c|}
\hline \multirow[b]{3}{*}{ Macroeconomic variable } & \multicolumn{2}{|c|}{ Baseline sample } & \multicolumn{2}{|c|}{$\begin{array}{l}\text { Accounting for cross-border } \\
\text { lending, sample with } \\
\text { relatively more local lenders }\end{array}$} & \multicolumn{2}{|c|}{$\begin{array}{l}\text { Accounting for cross- } \\
\text { border lending, adjusted } \\
\text { loan growth rates }\end{array}$} & \multicolumn{2}{|c|}{ Cross-border lending } & \multicolumn{2}{|c|}{$\begin{array}{l}\text { Accounting for the } \\
\text { number of banks }\end{array}$} \\
\hline & eq $(7)$ & eq $(9)$ & eq $(7)$ & eq $(9)$ & eq $(7)$ & eq $(9)$ & eq $(7)$ & eq $(9)$ & eq $(7)$ & eq $(9)$ \\
\hline & & & & & & & & & & \\
\hline GDP & $\begin{array}{c}0.7437 \\
(0.0160)^{* *}\end{array}$ & $\begin{array}{c}1.3230 \\
(0.0244)^{* *}\end{array}$ & $\begin{array}{c}0.6945 \\
(0.0279)^{* *}\end{array}$ & $\begin{array}{c}1.4042 \\
(0.0800)^{*}\end{array}$ & $\begin{array}{c}1.1366 \\
(0.0024)^{* * *}\end{array}$ & $\begin{array}{c}3.0593 \\
(0.0011)^{* * *}\end{array}$ & $\begin{array}{l}-0.6171 \\
(0.5708)\end{array}$ & $\begin{array}{c}-4.5954 \\
(0.0000)^{* * *}\end{array}$ & $\begin{array}{c}0.8592 \\
(0.0114)^{* *}\end{array}$ & $\begin{array}{c}1.8440 \\
(0.0855)^{*}\end{array}$ \\
\hline Unemployment & $\begin{array}{c}-0.1088 \\
(0.0047)^{* * *}\end{array}$ & $\begin{array}{l}-0.0378 \\
(0.6408)\end{array}$ & $\begin{array}{c}-0.1072 \\
(0.0350)^{* *}\end{array}$ & $\begin{array}{l}-0.0083 \\
(0.9381)\end{array}$ & $\begin{array}{l}-0.0748 \\
(0.1704)\end{array}$ & $\begin{array}{l}-0.1739 \\
(0.1032)\end{array}$ & $\begin{array}{l}-0.0997 \\
(0.3502)\end{array}$ & $\begin{array}{c}0.3423 \\
(0.0038)^{* * *}\end{array}$ & $\begin{array}{c}-0.1652 \\
(0.0026)^{* * *}\end{array}$ & $\begin{array}{l}-0.1382 \\
(0.3346)\end{array}$ \\
\hline Deposit rate & $\begin{array}{c}-0.0031 \\
(0.0071)^{* * *}\end{array}$ & $\begin{array}{l}-0.0386 \\
(0.2521)\end{array}$ & $\begin{array}{c}-0.0794 \\
(0.0001)^{* * *}\end{array}$ & $\begin{array}{c}-0.1287 \\
(0.0234)^{* *}\end{array}$ & $\begin{array}{c}-0.0060 \\
(0.0000)^{* * *}\end{array}$ & $\begin{array}{c}0.0174 \\
(0.8159)\end{array}$ & $\begin{array}{c}0.0017 \\
(0.0732)^{*}\end{array}$ & $\begin{array}{c}0.0110 \\
(0.8427)\end{array}$ & $\begin{array}{c}-0.0561 \\
(0.0138)^{* *}\end{array}$ & $\begin{array}{c}-0.1448 \\
(0.0718)^{*}\end{array}$ \\
\hline Ratios & & & & & & & & & & \\
\hline Capital Adequacy & $\begin{array}{c}0.0058 \\
(0.0000)^{* * *}\end{array}$ & $\begin{array}{c}0.0005 \\
(0.1636)\end{array}$ & $\begin{array}{c}0.0051 \\
(0.0004)^{* * *}\end{array}$ & $\begin{array}{c}0.0000 \\
(0.9892)\end{array}$ & $\begin{array}{c}0.0079 \\
(0.0001)^{* * *}\end{array}$ & $\begin{array}{c}0.0010 \\
(0.5685)\end{array}$ & $\begin{array}{c}0.0038 \\
(0.2073)\end{array}$ & $\begin{array}{c}0.0005 \\
(0.8161)\end{array}$ & $\begin{array}{c}0.0088 \\
(0.0001)^{* * *}\end{array}$ & $\begin{array}{c}0.0031 \\
(0.6846)\end{array}$ \\
\hline Asset Quality & $\begin{array}{c}0.0063 \\
(0.0963)^{*}\end{array}$ & $\begin{array}{c}0.0010 \\
(0.5866)\end{array}$ & $\begin{array}{c}0.0071 \\
(0.0808)^{*}\end{array}$ & $\begin{array}{l}-0.0029 \\
(0.6218)\end{array}$ & $\begin{array}{c}0.0071 \\
(0.0325)^{* *}\end{array}$ & $\begin{array}{l}-0.0015 \\
(0.8121)\end{array}$ & $\begin{array}{l}-0.0006 \\
(0.8370)\end{array}$ & $\begin{array}{c}0.0060 \\
(0.2474)\end{array}$ & $\begin{array}{c}0.0099 \\
(0.0033)^{* * * *}\end{array}$ & $\begin{array}{l}0.0057 \\
(0.5076)\end{array}$ \\
\hline Performance & $\begin{array}{c}0.0010 \\
(0.0001)^{* * *}\end{array}$ & $\begin{array}{c}0.0022 \\
(0.0889)^{*}\end{array}$ & $\begin{array}{c}0.0018 \\
(0.0000)^{* * *}\end{array}$ & $\begin{array}{c}0.0007 \\
(0.5911)\end{array}$ & $\begin{array}{c}0.0011 \\
(0.0002)^{* * *}\end{array}$ & $\begin{array}{c}0.0006 \\
(0.5950)\end{array}$ & $\begin{array}{l}-0.0001 \\
(0.7943)\end{array}$ & $\begin{array}{c}0.0014 \\
(0.4932)\end{array}$ & $\begin{array}{c}0.0013 \\
(0.0095)^{* * *}\end{array}$ & $\begin{array}{l}0.0022 \\
(0.1544)\end{array}$ \\
\hline Liquidity & $\begin{array}{c}0.0016 \\
(0.0000)^{* * *}\end{array}$ & $\begin{array}{l}-0.0002 \\
(0.6130)\end{array}$ & $\begin{array}{c}0.0018 \\
(0.0169)^{* *}\end{array}$ & $\begin{array}{l}-0.0002 \\
(0.7739)\end{array}$ & $\begin{array}{c}0.0018 \\
(0.0000)^{* * * *}\end{array}$ & $\begin{array}{l}-0.0001 \\
(0.9043)\end{array}$ & $\begin{array}{c}0.0001 \\
(0.7994)\end{array}$ & $\begin{array}{c}0.0021 \\
(0.0284)^{* *}\end{array}$ & $\begin{array}{c}0.0015 \\
(0.0000)^{* * * *}\end{array}$ & $\begin{array}{l}-0.0009 \\
(0.2624)\end{array}$ \\
\hline
\end{tabular}

Notes: This table reports the coefficients of the main independent variables (and their corresponding p-values) in equations (7) and (9) in column 1 and 2, respectively. The p-values are in parentheses. *,**, *** significant at $10 \%$, $5 \%, 1 \%$, respectively. 
Table 10. Sensitivity analysis, continued

\begin{tabular}{|c|c|c|c|c|c|c|c|c|}
\hline \multirow[b]{3}{*}{ Macroeconomic variabl } & \multicolumn{2}{|c|}{ Baseline sample } & \multicolumn{2}{|c|}{$\begin{array}{l}\text { Accounting for lending } \\
\text { shares }\end{array}$} & \multicolumn{2}{|c|}{ Accounting for distance } & \multicolumn{2}{|c|}{$\begin{array}{l}\text { Accounting for income per } \\
\text { capita }\end{array}$} \\
\hline & eq $(7)$ & eq $(9)$ & eq $(7)$ & eq $(9)$ & eq $(7)$ & eq $(9)$ & eq $(7)$ & eq $(9)$ \\
\hline & & & & & & & & \\
\hline GDP & $\begin{array}{c}0.7437 \\
(0.0160)^{* *}\end{array}$ & $\begin{array}{c}1.3230 \\
(0.0244)^{* *}\end{array}$ & $\begin{array}{c}13.6950 \\
(0.0000)^{* * *}\end{array}$ & $\begin{array}{l}-1.8324 \\
(0.3130)\end{array}$ & $\begin{array}{c}0.7739 \\
(0.0458)^{* *}\end{array}$ & $\begin{array}{c}2.3324 \\
(0.0231)^{* *}\end{array}$ & $\begin{array}{c}0.7201 \\
(0.0835)^{*}\end{array}$ & $\begin{array}{c}1.2373 \\
(0.0718)^{*}\end{array}$ \\
\hline Unemployment & $\begin{array}{c}-0.1088 \\
(0.0047)^{* * *}\end{array}$ & $\begin{array}{l}-0.0378 \\
(0.6408)\end{array}$ & $\begin{array}{c}-1.0210 \\
(0.0041)^{* * *}\end{array}$ & $\begin{array}{l}-0.9487 \\
(0.4480)\end{array}$ & $\begin{array}{c}-0.1090 \\
(0.0419)^{* *}\end{array}$ & $\begin{array}{l}-0.0682 \\
(0.6521)\end{array}$ & $\begin{array}{l}-0.0321 \\
(0.5776)\end{array}$ & $\begin{array}{l}-0.0231 \\
(0.8004)\end{array}$ \\
\hline Deposit rate & $\begin{array}{c}-0.0031 \\
(0.0071)^{* * *}\end{array}$ & $\begin{array}{l}-0.0386 \\
(0.2521)\end{array}$ & $\begin{array}{c}-0.5138 \\
(0.0210)^{* *}\end{array}$ & $\begin{array}{l}-0.0159 \\
(0.8678)\end{array}$ & $\begin{array}{c}-0.0028 \\
(0.0051)^{* * *}\end{array}$ & $\begin{array}{l}-0.0692 \\
(0.1185)\end{array}$ & $\begin{array}{c}-0.0021 \\
(0.0016)^{* * *}\end{array}$ & $\begin{array}{l}-0.0316 \\
(0.3539)\end{array}$ \\
\hline \multicolumn{9}{|l|}{ Ratios } \\
\hline Capital Adequacy & $\begin{array}{c}0.0058 \\
(0.0000)^{* * *}\end{array}$ & $\begin{array}{c}0.0005 \\
(0.1636)\end{array}$ & $\begin{array}{c}0.0114 \\
(0.0015)^{* * *}\end{array}$ & $\begin{array}{c}0.0029 \\
(0.6721)\end{array}$ & $\begin{array}{c}0.0057 \\
(0.0054)^{* * *}\end{array}$ & $\begin{array}{l}-0.0004 \\
(0.6546)\end{array}$ & $\begin{array}{c}0.0047 \\
(0.0001)^{* * *}\end{array}$ & $\begin{array}{l}-0.0002 \\
(0.8375)\end{array}$ \\
\hline Asset Quality & $\begin{array}{c}0.0063 \\
(0.0963)^{*}\end{array}$ & $\begin{array}{c}0.0010 \\
(0.5866)\end{array}$ & $\begin{array}{c}0.0267 \\
(0.1279)\end{array}$ & $\begin{array}{l}-0.0156 \\
(0.5460)\end{array}$ & $\begin{array}{c}0.0010 \\
(0.7928)\end{array}$ & $\begin{array}{l}-0.0021 \\
(0.5572)\end{array}$ & $\begin{array}{c}0.0060 \\
(0.2130)\end{array}$ & $\begin{array}{l}-0.0006 \\
(0.7960)\end{array}$ \\
\hline Performance & $\begin{array}{c}0.0010 \\
(0.0001)^{* * *}\end{array}$ & $\begin{array}{c}0.0022 \\
(0.0889)^{*}\end{array}$ & $\begin{array}{c}0.0059 \\
(0.0004)^{* * *}\end{array}$ & $\begin{array}{c}0.0096 \\
(0.3162)\end{array}$ & $\begin{array}{c}0.0013 \\
(0.0001)^{* * *}\end{array}$ & $\begin{array}{c}0.0024 \\
(0.2004)\end{array}$ & $\begin{array}{c}0.0006 \\
(0.0405)^{* *}\end{array}$ & $\begin{array}{c}0.0020 \\
(0.1505)\end{array}$ \\
\hline Liquidity & $\begin{array}{c}0.0016 \\
(0.0000)^{* * *}\end{array}$ & $\begin{array}{l}-0.0002 \\
(0.6130)\end{array}$ & $\begin{array}{c}0.0009 \\
(0.0685)^{*}\end{array}$ & $\begin{array}{c}0.0064 \\
(0.0008)^{* * *}\end{array}$ & $\begin{array}{c}0.0017 \\
(0.0838)^{*}\end{array}$ & $\begin{array}{l}-0.0003 \\
(0.6553)\end{array}$ & $\begin{array}{c}0.0015 \\
(0.0000)^{* * *}\end{array}$ & $\begin{array}{c}0.0000 \\
(0.9959)\end{array}$ \\
\hline
\end{tabular}

Notes: This table reports the coefficients of the main independent variables (and their corresponding p-values) in equations (7) and (9) in column 1 and 2, respectively. The p-values are in parentheses. *, **, *** significant at $10 \%$, $5 \%, 1 \%$, respectively. 


\section{Table 11. Capital controls}

\begin{tabular}{|c|c|c|c|c|c|c|c|}
\hline & \multicolumn{3}{|c|}{ Macroeconomic variables } & \multicolumn{4}{|c|}{ Banks' ratios } \\
\hline & GDP & Unemployment & Deposit rate & Capital Adequacy & Asset Quality & Performance & Liquidity \\
\hline \multicolumn{8}{|c|}{ Subsidiary and host-nation specific factors } \\
\hline \multirow{2}{*}{$\gamma_{1}^{h}$} & 0.4319 & -0.0733 & -0.0109 & 0.0055 & 0.0073 & 0.0014 & 0.0012 \\
\hline & $(0.2049)$ & $(0.0836)^{*}$ & $(0.0625)^{*}$ & $(0.0005)^{* * *}$ & $(0.0805)^{*}$ & $(0.0004)^{* * *}$ & $(0.0203)^{* *}$ \\
\hline \multirow[t]{2}{*}{ Capital controls } & 0.0639 & 0.0670 & 0.0833 & 0.0789 & 0.0781 & 0.0627 & 0.0573 \\
\hline & $(0.0520)^{*}$ & $(0.0550)^{*}$ & $(0.0084)^{* * *}$ & $(0.0287)^{* *}$ & $(0.0247)^{* *}$ & $(0.0741)^{*}$ & $(0.0896)^{*}$ \\
\hline \multicolumn{8}{|c|}{ Owner and lending-nation specific factors } \\
\hline \multirow[t]{2}{*}{$\gamma_{1}^{l}$} & 0.9467 & 0.0700 & 0.0226 & -0.0062 & 0.0162 & 0.0010 & 0.0002 \\
\hline & $(0.4032)$ & $(0.5238)$ & $(0.7195)$ & $(0.4242)$ & $(0.3803)$ & $(0.5565)$ & $(0.7932)$ \\
\hline \multirow[t]{2}{*}{ Capital controls } & 0.0419 & 0.0401 & -0.0185 & 0.0698 & 0.0548 & 0.0549 & 0.0553 \\
\hline & $(0.0267)^{* *}$ & $(0.0354)^{* *}$ & $(0.5955)$ & $(0.0001)^{* * *}$ & $(0.0251)^{* *}$ & $(0.0041)^{* * *}$ & $(0.0025)^{* * *}$ \\
\hline
\end{tabular}

Notes: To obtain the results in this table we add a capital controls variable to the right hand sides of equations (7) and (9). The top panel reports the coefficients of the main independent variable (and their corresponding p-values) and the coefficient of the capital controls variable, in this extended version of equations (7) and the bottom panel does the same for equation (9). The p-values are in parentheses. *, **,*** significant at $10 \%, 5 \%, 1 \%$, respectively. 
Table 12. Comparing the economic significance of ratios, subsidiary versus owner

\begin{tabular}{|c|c|c|c|c|c|}
\hline & eq $(7)$ & eq $(9)$ & & eq $(7)$ & eq $(9)$ \\
\hline Capital Adequacy & & & Asset Quality & & \\
\hline Equity / Tot Assets & 0.0502 & 0.0309 & Loan Loss Prov / Net Int Rev & -0.0223 & -0.0144 \\
\hline Equity / Net Loans & 0.1153 & 0.0893 & Loan Loss Res / Impair. Loans & 0.0458 & -0.0114 \\
\hline Equity / Cust \& ST Funding & 0.0566 & 0.0331 & Unres. Impair. Loans / Equity & -0.0339 & -0.0304 \\
\hline Equity / Liabilities & 0.0408 & 0.0327 & $\underline{\text { Performance }}$ & & \\
\hline Cap Funds / Tot Assets & 0.0645 & 0.0333 & Return On Avg Equity (ROAE) & 0.0210 & 0.0142 \\
\hline Cap Funds / Net Loans & 0.0895 & 0.0877 & Inc Net Of Dist / Avg Equity & 0.0283 & 0.0140 \\
\hline
\end{tabular}

Notes: This table reports the estimated coefficients of the ratios that are the main independent variables in equations (7) and (9). The coefficients represent the percentage point response of lending to a one standard deviation change in the ratio. The bold italic values are larger in absolute value than their counterparts in the same column pair. 